\title{
Expanding the scope of prenylated 1,2,3-triazoles as new antiparasitic drug candidates
}

\author{
Renzo Carlucci, ${ }^{\mathrm{a}, \mathrm{f}}$ Gabriel Di Gresia, ${ }^{\mathrm{a}, \mathrm{F}}$ Babu L. Tekwani, ${ }^{\mathrm{b}}$ Shabana I. Khan, ${ }^{\mathrm{c}}$ and Guillermo R. Labadie., ${ }^{\mathrm{a},{ }^{*}}$
}

anstituto de Química Rosario, UNR, CONICET, Suipacha 531, S2002LRK, Rosario, Argentina. E-mail: labadie@iquir-conicet.gov.ar; Fax: +54 341 4370477; Tel: +54 3414370477.

${ }^{\mathrm{b} D}$ Department of Infectious Diseases, Scientific Platforms, Southern Research, Birmingham, AL 35205, USA

${ }^{c}$ National Center for Natural Products Research \& Department of Biomolecular Sciences, School of Pharmacy, University of Mississippi, University MS 38677, USA

dDepartamento de Química Orgánica, Facultad de Ciencias Bioquímicas y Farmacéuticas, Universidad Nacional de Rosario, Suipacha 531, S2002LRK, Rosario, Argentina

\#These authors contributed equally to this work.

*Corresponding author: Instituto de Química Rosario (IQUIR-CONICET), Facultad de Ciencias Bioquímicas y Farmacéuticas, Universidad Nacional de Rosario. Suipacha 531, S2002LRK, Rosario, ARGENTINA. Tel/Fax: +54-341-4370477 E-mail: labadie@iquir-conicet.gov.ar

\begin{abstract}
We have previously shown that prenyl and aliphatic triazoles are interesting motifs to prepare new chemical entities for antiparasitic and antituberculosis drug development. In this opportunity a new series of prenyl-1,2,3-triazoles were prepared from isoprenyl azides and different alkynes looking for new antimalarial drug candidates. The compounds were prepared by copper(I) catalyzed dipolar cycloaddition of the isoprenyl azide equilibrium mixture providing exclusively 1,4-disubstituted 1,2,3-triazols in a regiospecific fashion. The complete collection of 64 compounds was tested on chloroquine -sensitive, Sierra Leone (D6), and the chloroquine-resistant, Indochina (W2), strains of Plasmodium falciparum and those compounds which were not previously reported were also tested against Leishmania donovani, the causative agent for visceral leishmaniasis. Thirteen analogs displayed antimalarial activity with $\mathrm{IC}_{50}$ below $10 \mu \mathrm{M}$, while the antileishmanial activity was less potent than the previously reported analogs. The cytotoxicity assay against Vero cells revealed that none of the compounds was cytotoxic up to concentrations of $4.75 \mu \mathrm{g} / \mathrm{mL}$. Compounds 10 and $1 \mathrm{r}$ were identified as the most promising antimalarial drug leads with $\mathrm{IC}_{50}$ below $3.0 \mu \mathrm{M}$ for both CQ-sensitive and resistant $P$. falciparum strains. Finally, a chemoinformatic in silico analysis was performed to evaluate physicochemical parameters, cytotoxicity risk and drug score. The validation of a bifunctional farnesyl/geranylgeranyl diphosphate synthase PfFPPS/GGPPS as the potential target of the antimalarial activity of selected analogs should be further investigated.
\end{abstract}

\section{Introduction}

Neglected tropical diseases (NTDs) are a group of infectious pathologies prevalent in intertropical and subtropical countries with deficient health, socioeconomic and environmental conditions. ${ }^{1}$ These diseases are considered neglected because they are widespread among poor and outcast populations that live in rural areas of developing countries. Those conditions are favourable for propagating the vectors that transmit most of NTDs. Malaria ${ }^{2}$ and leishmaniasis ${ }^{3}$ are two infectious diseases that affect an enormous part of the tropical and subtropical population in the World.

Malaria is a parasitic disease transmitted by the female mosquito from Anopheles genus. Plasmodium spp are the etiological agents of the disease with five species that can infect humans. $P$. falciparum has the highest prevalence and severity of the infection and is mostly found in sub-Saharan Africa. In Africa, the infections by this parasite are responsible for most of mortality in children. $P$. vivax, which is mostly endemic of Asia and South America, ${ }^{4,5}$ is now recognized as fatal. ${ }^{6}$ With up to 300 million of infections every year, and up to 2,500 million people in risk, $P$. vivax is a significant threat for all developing countries in tropical and subtropical regions. The strengthening of prevention and control measures has led to a $29 \%$ reduction in mortality rates by malaria around the world since 2010. Sub-Saharan Africa keeps having a highly unequal share of the World's malaria cases and deaths. ${ }^{2}$

Leishmaniasis is a parasitic disease caused by Leishmania spp, with over 20 species that causes different clinical manifestations. The infection has three different forms known as cutaneous (CL), mucocutaneous (ML) and visceral (VL), damaging the skin, mucous or organs, respectively. The parasites are transmitted to the host by the bite of female mosquito of Phlebotomus genus (Africa and Asia) or Lutzomyia genus (Latin America). This endemic disease affects the population of more than 98 countries with a global prevalence of 12 million people. $\mathrm{CL}$ is mainly distributed along Middle Eastern and Latin American regions, whereas VL is mostly founded in India, East Africa and Brazil. ${ }^{3}$ Over the last 10 years there were a world epidemic expansion in VL which has a high probability of death in untreated cases within the first 2 years. ${ }^{7,8}$ 
There are areas where visceral leishmaniasis $(\mathrm{VL})$ is co-endemic with malaria, being possible the co-infections with both diseases. There are different reports with cases of co-infection of these parasites in humans in different region of Africa. ${ }^{9,10}$ Therefore, there is a need to identify optimal and cost-effective strategies to control co-infections to reduce the risk of spreading these diseases. ${ }^{11}$ Chloroquine has been the first line drug for malaria treatment, but due to emergence of resistance, new treatments, like the artemisinin combination therapy (ACT) are recommended by the WHO. ${ }^{12-14}$ (Fig. 1) For leishmaniasis, Sb(V) derivatives are still first line treatment, together with amphotericin B, miltefosine, pentamidine, and paromomycin. The first two are the preferred chemotherapy despite the high toxicity and development of resistance. ${ }^{15}$ (Fig. 1) Therefore, more effective antiparasitic agents with novel mechanism of action and no side-effects are needed.

The isoprene biosynthesis is linked to metabolites that are required to the cellular viability, like dolichol, ubiquinone and heme $A$. Isoprenes are also involved on the post-translational modification of proteins required for anchoring to the membrane. ${ }^{16} P$. falciparum and L. donovani, like most of eukaryotes, possess prenyltransferases that incorporate farnesyl or geranylgeranyl on substrate proteins. ${ }^{17-19}$
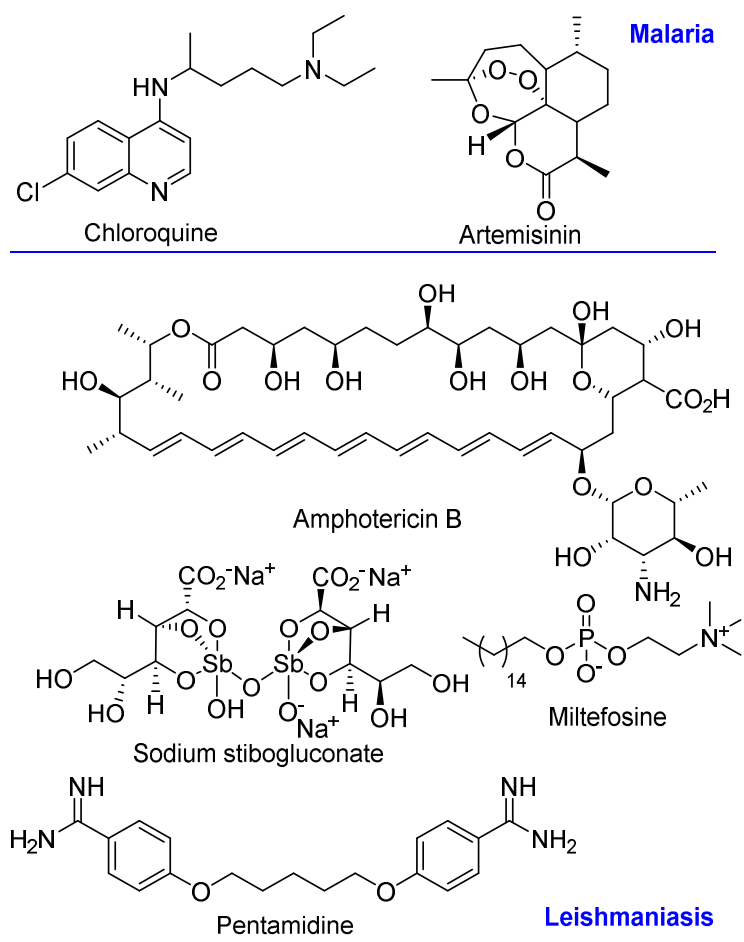

Fig. 1. Available drugs for malaria and leishmaniasis treatment.

The inhibition of the isoprenoid biosynthesis blocks the proteins prenylation and is lethal for $P$. falciparum and $L$. donovani. One important enzyme of that essential pathway is the farnesyl pyrophosphate synthase (FPPS). FPPS has been pointed out as drug target for parasitic diseases, including malaria and leishmaniasis. ${ }^{20}$ Bisphosphonates that were initially introduced as bone disorder drug candidates, lately has become the preferred scaffold to develop new inhibitors of FPPS. ${ }^{21}$ In fact, over the last years different biphosphonates have been reported as FPPS inhibitor displaying activity on $P$. vivax, ${ }^{22}$ on the liver stage assays and in vivo. ${ }^{23}$ Interestingly, the compounds also inhibit geranylgeranyl pyrophosphate synthase (GGPPS), which has emerged as a new target for antimalarial drug development. ${ }^{24,25}$ Other bisphosphonate derivatives have displayed activity against $T$. cruzi and T. gondii, ${ }^{26}$ where the fatty acids substituted analogs have showed significant inhibition of the FPPS of different neglected diseases related parasites. $^{27-29}$

Plasmodium falciparum possess an enzyme responsible for the synthesis of farnesyl pyrophosphate, which is different to the FPPS from human, Leishmania genus, and other organisms. This parasite is believed to have a bifunctional enzyme that synthesizes both farnesyl pyrophosphate and geranylgeranyl pyrophosphate, called Bifunctional Farnesyl/Geranylgeranyl Diphosphate Synthase (PfFPPS/GGPPS, TDR Target data base name: PF3D7_1128400). This enzyme is a validated target in malaria, although the classic inhibitors of FPPS have little bioavailability and low inhibitory activities. ${ }^{30}$ Thereby, more studies related to the inhibition of the enzyme are needed.

The synthetic accessibility of 1,2,3-triazoles by CUAAC, the flagship reaction of the "Click chemistry", have broken into the medicinal chemistry arena being extensively used to prepare new collection of putative active compounds. ${ }^{31,32}$ Drug discovery on parasitic diseases, including malaria ${ }^{33,34}$ and leishmaniasis, ${ }^{35}$ has not been an exception where many examples of active 1,2,3-triazoles have been reported. ${ }^{36}$ Some examples of antimalarial 1,2,3 triazoles $^{37}$ including naphtyl derivatives, ${ }^{38}$ are shown on Fig. 2. 


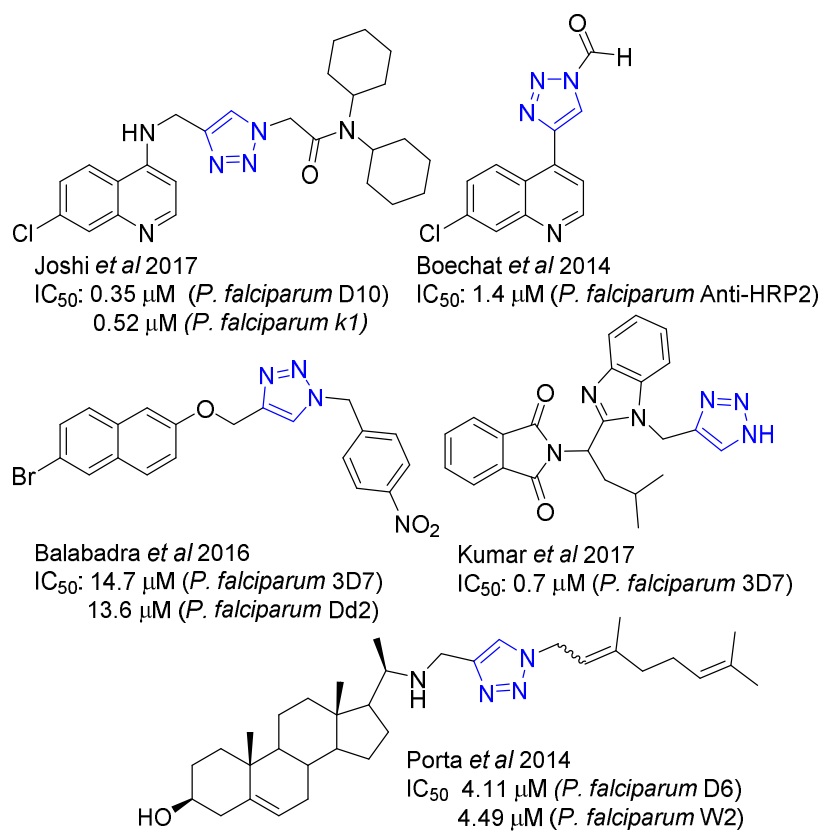

Fig. 2. Reported antimalarial 1,2,3-triazolyl derivatives.

An interesting example recently reported by our group is the class of isoprenyl 1,2,3-triazoles. Those compounds displayed low micromolar activity against $T$. cruzi and $L$. donovani, ${ }^{39}$ being promising antiparasitic candidates.

\section{Results and discussion}

\subsection{Design and Synthesis}

Looking to find new antiparasitic 1,2,3-triazoles we decided to expand the previously reported collection of our group. (Fig. 3) As can be seen, those compounds are mostly $\mathrm{N}_{1}$-prenylated-1,2,3-triazoles holding non-polar substituents on C4.

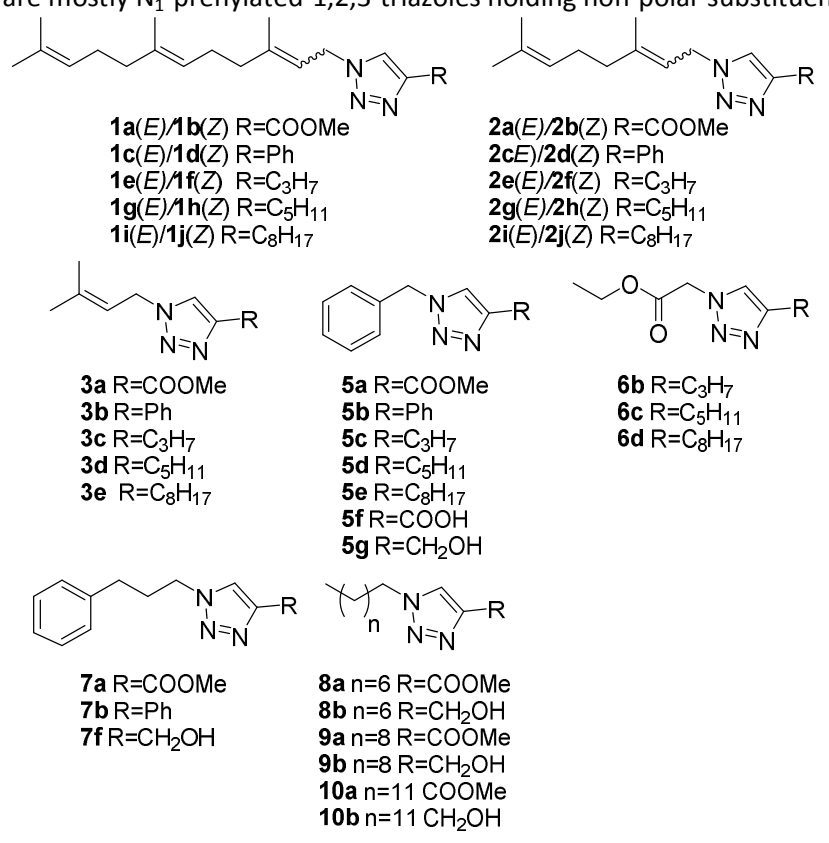

Fig. 3. Previously reported 1,2,3-triazoles

In order to target FPPS/GGPPS, a substrate mimic should have an isoprenyl chain and polar group that will fill the pyrophosphate pocket. To that purpose the new analogs series will include hydroxy-groups on the C4-substituent. (Fig. 4) Additionally, to expand the collection covering a wide spectrum of steric and electronic demand, phenyl-alkylated substituents were also introduced. 


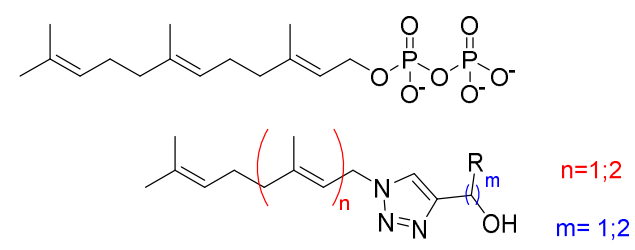

Fig. 4: Potential substrate mimic structures

The necessary azides were prepared following previously reported procedures. ${ }^{40}$ Cinnamyl azide and prenyl azides were prepared from the corresponding alcohols by the Thompson's reaction. ${ }^{41}$ Farnesyl and geranyl azides were obtained as a mixture of regioisomers that interconvert rapidly at room temperature, due to a [3,3]-sigmatropic Winstein's rearrangement. ${ }^{39}$ On the contrary, cinnamyl azide is not in equilibrium with its tertiary isomer as has been previously reported. ${ }^{42}$ Once the necessary building blocks were synthetized, CuAAC conditions were used to prepare the 1,4-disubstituted 1,2,3-triazoles.

The reactions were conducted using $\mathrm{CuSO}_{4}$ as the copper source, sodium ascorbate as a reductant in a ${ }^{\mathrm{t}} \mathrm{BuOH}: \mathrm{H}_{2} \mathrm{O}$ mixture. ${ }^{43}$ Eight terminal alkynes were used as a synthetic counterpart of the allylic azides. (Scheme 1)

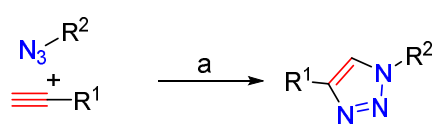

a) CuSO4, sodium ascorbate, $\mathrm{H}_{2} \mathrm{O}: \mathrm{t}-\mathrm{BuOH}$, room temp, $18 \mathrm{~h}$.

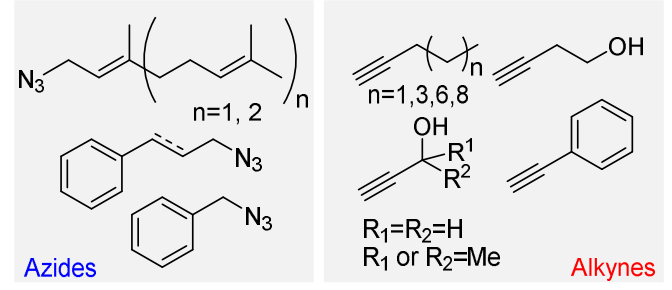

Scheme 1. Synthesis of $1,2,3$ triazoles collection

Following that procedure, four farnesyl derivatives were obtained as $E: Z$ (1:2) mixture and were separated by column chromatography.(Fig. 5) Additionally, five cinnamyl and five phenyl propyl analogs were also obtained.(Fig. 5) Finally, the C10 derivative of the $\mathbf{5}$ series (compound $\mathbf{5}$ ) and the diester $\mathbf{6 a}$ were also prepared. Together the compounds added to the previous collection (Fig. 4) were obtained with a $77 \%$ average yield after purification.

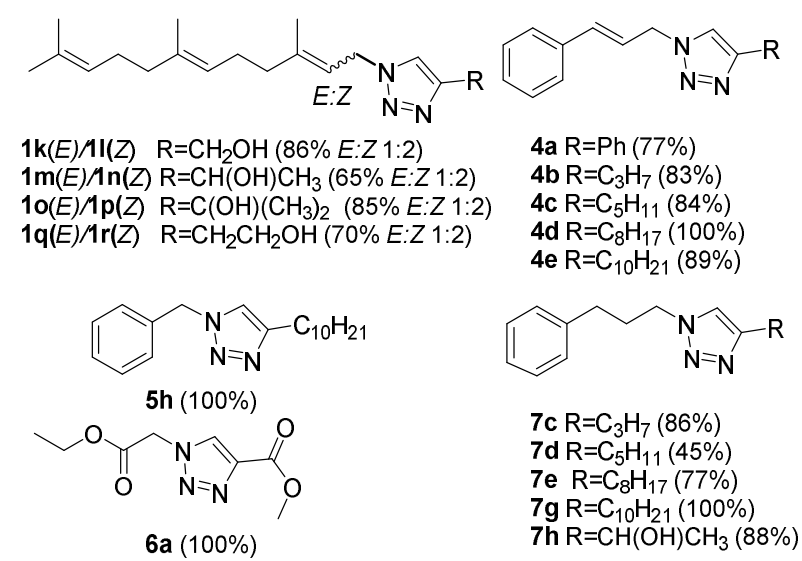

Fig. 5. 1,2,3-triazoles synthesized in this work.

\subsection{Biology}

\subsubsection{Antiplasmodial activity}

The collection including the 44 previously reported analogues and 20 new derivatives were assayed against the chloroquine sensitive, Sierra Leone clone (D6), and the chloroquine resistant, Indochina clone (W2), strains of $P$. falciparum. To our satisfaction, 13 compounds ( $20 \%$ of the collection) were active against both strains. (Table 1, Fig. 6)

The active compounds present $\mathrm{IC}_{50}$ below $30 \mu \mathrm{M}$, with the most active members in the low micromolar range. Interestingly, there is no significant difference between the antimalarial activity for both strains and over half of the active compounds exhibited a selectivity index greater than 1.5 . 


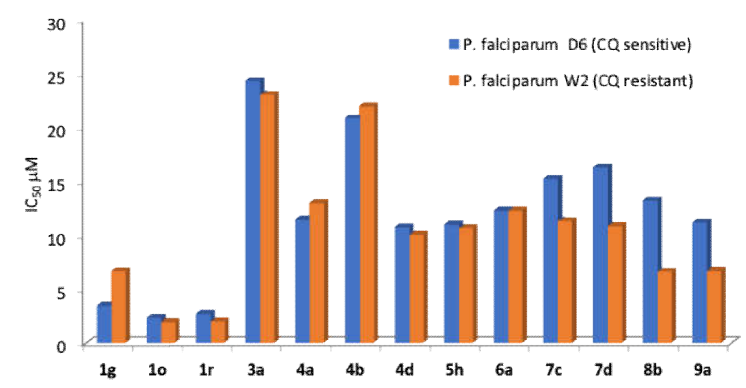

Fig. 6. Compounds active against $P$. falciparum

Table 1. Antimalarial activity of the 1,2,3-triazole derivatives.

\begin{tabular}{|c|c|c|c|c|c|c|c|c|}
\hline Cmpd & azide & $\mathbf{R}$ & $E / Z$ & $\begin{array}{l}\text { P. f. } \mathrm{D6}^{1} \\
\mathrm{IC}_{50} \mu \mathrm{M}\end{array}$ & SI & $\begin{array}{l}\text { P. f. W2 } \\
\mathrm{IC}_{50} \mu \mathrm{M}\end{array}$ & SI & $\begin{array}{c}\text { Cytotoxicity } \\
\text { Vero cells }\end{array}$ \\
\hline $1 \mathrm{~g}$ & farnesyl & $\mathrm{C}_{5} \mathrm{H}_{11}$ & $E$ & 3.49 & $>3.96$ & 6.69 & $>2.07$ & NC \\
\hline 10 & farnesyl & $\mathrm{C}(\mathrm{OH})\left(\mathrm{CH}_{3}\right)_{2}$ & $E$ & 2.35 & $>6.09$ & 1.99 & $>7.20$ & NC \\
\hline $1 r$ & farnesyl & $\mathrm{CH}_{2} \mathrm{CH}_{2} \mathrm{OH}$ & $z$ & 2.74 & $>5.46$ & 2.05 & $>7.31$ & NC \\
\hline $3 a$ & prenyl & coOMe & - & 24.3 & $>1$ & 23.1 & 1.06 & NC \\
\hline $4 a$ & cinnamyl & $\mathrm{Ph}$ & - & 11.5 & $>1.58$ & 13.0 & $>1.40$ & NC \\
\hline $4 b$ & cinnamyl & $\mathrm{n}-\mathrm{C}_{3} \mathrm{H}_{7}$ & - & 20.9 & $<1$ & 22.0 & $<1$ & NC \\
\hline $4 d$ & cinnamyl & I $n-C_{8} \mathrm{H}_{17}$ & - & 10.8 & $>1.48$ & 10.1 & $>1.58$ & NC \\
\hline $5 \mathrm{~h}$ & benzyl & $\mathrm{n}-\mathrm{C}_{10} \mathrm{H}_{21}$ & - & 11.0 & $>1.44$ & 10.7 & $>1.48$ & NC \\
\hline $6 a$ & $\mathrm{CH}_{2} \mathrm{COOEt}$ & $\mathrm{t}$ COOMe & - & 12.3 & $>1.70$ & 12.3 & $>1.70$ & NC \\
\hline $7 c$ & $\left(\mathrm{CH}_{2}\right)_{3} \mathrm{Ph}$ & $\mathrm{n}-\mathrm{C}_{3} \mathrm{H}_{7}$ & - & 15.3 & $>1.36$ & 11.3 & $>1.83$ & NC \\
\hline $7 d$ & $\left(\mathrm{CH}_{2}\right)_{3} \mathrm{Ph}$ & $\mathrm{n}-\mathrm{C}_{5} \mathrm{H}_{11}$ & - & 16.3 & $>1.13$ & 10.9 & $>1.70$ & NC \\
\hline $8 b$ & $\mathrm{n}-\mathrm{C}_{8} \mathrm{H}_{17}$ & $\mathrm{CH}_{2} \mathrm{OH}$ & - & 13.3 & $>1.70$ & 6.63 & $>3.39$ & NC \\
\hline $9 a$ & $\mathrm{n}-\mathrm{C}_{10} \mathrm{H}_{21}$ & COOMe & - & 11.2 & $>1.58$ & 6.73 & $>2.64$ & NC \\
\hline CHQ & & & & 0.083 & & 0.422 & & \\
\hline ART & & & & 0.094 & & 0.094 & & \\
\hline
\end{tabular}

\subsubsection{Antileishmanial activity}

The activity on Leishmania donovani promastigotes of 25 analogues (1a-1j; $\mathbf{2 a - 3 e ) ~ h a v e ~ b e e n ~ p r e v i o u s l y ~ r e p o r t e d ~ b y ~ o u r ~ g r o u p . ~}{ }^{39}$ The most active members of that initial study were $\mathbf{1 b}$ and $\mathbf{1 h}$ with $\mathrm{IC}_{50}$ of $11 \mu \mathrm{M}$. In order to expand the SAR the activity of the 39 compounds not previously reported was evaluated. The activity of those compounds is presented in Table 2, where only 15 analogs ( $60 \%$ of the new compounds) were active. In this case any analogs displayed an $\mathrm{IC}_{50}$ below $15 \mu \mathrm{M}$, as happened with the previous reported. In this case, 12 of the actives showing $\mathrm{IC}_{50}$ between 50 to $92 \mu \mathrm{M}$, demonstrating that analogs with the combination of an isoprene chain and non-polar substitutes were the most effective combinations against leishmania.

\subsubsection{In vitro cytotoxicity assay on Vero cells}

All the analogs were tested for cytotoxicity towards VERO (monkey kidney fibroblast) cells by Neutral Red assay. They did not show any cytotoxicity at the maximum concentration tested $(4.75 \mu \mathrm{g} / \mathrm{mL})$. Considering this information, the most active compounds 10 and $1 \mathrm{r}$ would have $\mathrm{IC}_{50}>14.3 \mu \mathrm{M}$ and $>15.0 \mu \mathrm{M}$, respectively for cytotoxicity. Those values correspond to selectivity index $>6.09$ (P.f. D6) and $>7.20$ (P.f. W2) for $\mathbf{1 0}$ and $>5.46$ (P.f. D6) and >7.31 (P.f. W2) for $\mathbf{1 r}$, indicating them as good candidates to advance to in vivo studies. ${ }^{44}$

\subsubsection{Structure Activity Relationship (SAR)}

In the previous sections the antiparasitic activity against $L$. donovani and $P$. falciparum were presented. In order to compare the activities and identify patterns, an activity heatmap was prepared. (Fig. 7) The best candidates for each pathogen are shown on a brighter tone of green. On the one side, the most active analogs against $L$. donovani are derivatives that belong to our previous report (Fig. $\mathbf{7}$ previous collection; compounds $\mathbf{1 a} \mathbf{-} \mathbf{1 j}$ and $\mathbf{2 a - 3 e )}$ ). On the other side, the analogs displaying better antimalarial activity mostly are compounds reported in this work (Fig. 7 this work; compounds $1 \mathbf{k}-1 \mathbf{r}$ and $4 \mathbf{a}-10 \mathrm{~b}$ ). A detailed analysis of the of the antimalarial activity through the $R$ substituents revealed some interesting patterns. The derivatives with aliphatic tails $(\mathbf{4 b} \mathbf{b}, \mathbf{4 d}, \mathbf{5 h}$, 
$\mathbf{5 c}$ and $\mathbf{7 d}$ ) or non-polar substituents $(\mathbf{3 a}, \mathbf{6 a}$ and $\mathbf{9 a})$ were in general less active. None of the analogs mentioned before have $\mathrm{IC}_{50}$ below $10 \mu \mathrm{M}$, ranging from $24.3 \mu \mathrm{M}$ for the less active (3a) to $11.0 \mu \mathrm{M}$ for $5 \mathrm{~h}$ the most active.

Table 2. Antileishmanial activity of the 1,2,3-triazole derivatives.

\begin{tabular}{|c|c|c|c|c|c|}
\hline Cmpd & azide & $\mathbf{R}$ & $E / Z$ & $\begin{array}{l}\text { L.d. Promastigotes } \\
\mathrm{IC}_{50} \mu \mathrm{M}\end{array}$ & $\begin{array}{l}\text { Cytotoxicity } \\
\text { Vero cells }\end{array}$ \\
\hline $1 \mathrm{k}$ & farnesyl & $\mathrm{CH}_{2} \mathrm{OH}$ & $E$ & 56.0 & NC \\
\hline 11 & farnesyl & $\mathrm{CH}_{2} \mathrm{OH}$ & z & 59.3 & NC \\
\hline $1 \mathrm{~m}$ & farnesyl & $\mathrm{CH}(\mathrm{OH})\left(\mathrm{CH}_{3}\right)_{2}$ & $\mathrm{E}$ & 56.7 & NC \\
\hline $1 n$ & farnesyl & $\mathrm{CH}(\mathrm{OH})\left(\mathrm{CH}_{3}\right)_{2}$ & z & 59.9 & NC \\
\hline 10 & farnesyl & $\mathrm{C}(\mathrm{OH})\left(\mathrm{CH}_{3}\right)_{2}$ & $\mathrm{E}$ & 48.3 & NC \\
\hline $1 p$ & farnesyl & $\mathrm{C}(\mathrm{OH})\left(\mathrm{CH}_{3}\right)_{2}$ & z & 63.4 & NC \\
\hline $1 q$ & farnesyl & $\mathrm{CH}_{2} \mathrm{CH}_{2} \mathrm{OH}$ & E & 63.0 & NC \\
\hline $1 r$ & farnesyl & $\mathrm{CH}_{2} \mathrm{CH}_{2} \mathrm{OH}$ & z & 63.0 & NC \\
\hline $4 c$ & cinnamyl & $\mathrm{n}-\mathrm{C}_{5} \mathrm{H}_{11}$ & - & 74.4 & NC \\
\hline $5 a$ & benzyl & coOMe & - & 92.1 & NC \\
\hline $5 b$ & benzyl & $\mathrm{Ph}$ & - & 85.0 & NC \\
\hline $5 e$ & benzyl & $n-\mathrm{C}_{8} \mathrm{H}_{17}$ & - & 22.1 & NC \\
\hline $5 f$ & benzyl & $\mathrm{COOH}$ & - & 18.7 & NC \\
\hline $7 b$ & $\left(\mathrm{CH}_{2}\right)_{3} \mathrm{Ph}$ & $\mathrm{Ph}$ & - & 68.4 & $\mathrm{NC}$ \\
\hline $9 a$ & $\mathrm{n}-\mathrm{C}_{10} \mathrm{H}_{21}$ & coome & - & 78.5 & NC \\
\hline Pen & & & & 6.17 & \\
\hline Amp & & & & 0.35 & \\
\hline
\end{tabular}

When the antiplasmodial activity was compared through the azide substituent, in general the derivatives presenting aromatic ring or aliphatic tails display activities between 10 to $20 \mu \mathrm{M}$. That is the case of the phenyl 3a, benzyl $\mathbf{5 h}$ and alkyl phenyl derivatives $7 \mathrm{c}$ and $\mathbf{7 d}$ (24.3, 11.0, 15.3 and $16.3 \mu \mathrm{M}$, respectively) and the cinnamyl derivatives $4 \mathbf{4 a}$, $\mathbf{b}$ and $\mathbf{4 d}(11.5,20.9$ and $10.8 \mu \mathrm{M}$, respectively). The compounds prepared from aliphatic azide (8b and $\mathbf{9 a}$ ) also showed similar potency (13.3 and $11.2 \mathrm{uM})$. Finally, the compounds with farnesyl chains were those displaying the best antimalarial activity. Those compounds have $\mathrm{IC}_{50} \mathrm{~S}$ below $4 \mu \mathrm{M}$ being 3 to 5 times more potent than the rest of the analogs that display antimalarial activity. The analog $1 \mathrm{~g}$ has an $\mathrm{IC}_{50}$ of $3.49 \mu \mathrm{M}$ on CQ-sensitive $P$. falciparum (D6) but was considerably less active on the CQ-resistant strain W2 (6.69 $\mu \mathrm{M})$. The other farnesylated 1,2,3-triazoles derivatives are compounds 10 and $\mathbf{1 r}$ which are the two most potent antimalarial compounds of the whole collection. Compound 10 has an $\mathrm{IC}_{50}$ of $2.35 \mu \mathrm{M}$ and $\mathbf{1 r}$ has an $\mathrm{IC}_{50}$ of $2.74 \mu \mathrm{M}$, for the CQ-sensitive strain D6. Interestingly, they were slightly more active on the CQ-resistant strain $\mathrm{W} 2$ with $\mathrm{IC}_{50}$ of 1.99 and $2.05 \mu \mathrm{M}$, respectively, being therefore very promising candidates. Another interesting outcome of this series is the regiochemistry of the farnesyl chain. On the one side, $\mathbf{1 g}$ and $\mathbf{1 0}$ were $Z$ and on the other side $1 \mathrm{r}$ was $E$, while their regioisomers were inactive. In summary, the combination of substituents with alcohols and farnesyl chains seems to enhance the antimalarial activity being promising candidates for future studies.

A more detailed look at the antileishmanial activity revealed that farnesyl derivatives $\mathbf{1} \mathbf{k}-\mathbf{1} \mathbf{r}$ displayed $\mathrm{IC}_{50}$ between 48.27 to 63.00 $\mu \mathrm{M}$. The activity of the previously reported prenylated 1,2,3-triazoles was highly dependent on the size of the isoprenyl units, where the farnesyl derivatives were the most active. The antileishmanial activity of the farnesyl series $\mathbf{1 a}-\mathbf{1 j}$, that range from 11.00 to $52.00 \mu \mathrm{M}$, was considerably more potent than $\mathbf{1 k} \mathbf{k}-\mathbf{1 r}$. The main difference between both series is the hydroxyl group on the alkyl substituent present on analogues $\mathbf{1 k}-\mathbf{1} \mathbf{r}$ that seems to be detrimental for the activity. As an example, $\mathbf{1 b}(Z, E$-farnesyl $\mathrm{R}=\mathrm{COOMe})$ has an $\mathrm{IC}_{50}$ of $11 \mu \mathrm{M}$ that increased to $59 \mu \mathrm{M}$ on $\mathbf{1 I}\left(\mathrm{Z}, \mathrm{E}\right.$-farnesyl $\left.\mathrm{R}=\mathrm{CH}_{2} \mathrm{OH}\right)$.

The other series contain aromatic substituents, including benzyl, cinnamyl and 3-phenyl propyl that have $\mathrm{IC}_{50}$ ranging from 18.70 to $92.70 \mu \mathrm{M}$. The most active member of the newly reported compounds belongs to the benzyl series. Analog 5e, a non-polar derivative holding a pentyl substituent, has an $\mathrm{IC}_{50}$ of $22 \mu \mathrm{M}$ and $\mathbf{5 f}$, a very simple carboxylic acid, is the most active member of the new collection having an $\mathrm{IC}_{50}$ of $18.70 \mu \mathrm{M}$.

In summary, the newly introduced analogues did not improve the activity of the previously reported derivatives $\mathbf{1 b}$ and $\mathbf{1 h}$, nevertheless, the structurally simple derivative $\mathbf{5 f}$ seems to be an interesting structure to further developed as antileishmanial agent.

It has been recently reported that MMV019313, a non-bisphosphonate FPPS inhibitor, is capable of inhibiting Pf FPPS/GGPPS in a non-conventional way. ${ }^{45}$ Indeed, MMV019313 interact with the enzyme in a non-catalytic site being 100 -times more selective to $P f$ FPPS/GGPPS than hFPPS. Gisselberg et al have proposed that $P f$ FPPS/GGPPS could have an allosteric inhibition site like the human enzyme. ${ }^{30}$ Unfortunately, the site has not been characterized in the plasmodial enzyme yet and molecular docking in the apo $P V$ FPPS/GGPPS structure was inconclusive.

Nevertheless, we can hypothesize that the antimalarial activity of these farnesylated derivatives may be related to the inhibition of Pf FPPS/GGPPS or another isoprene biosynthesis enzyme knowing the essentiality of these important metabolites. Such as the case of protein farnesyl transferase, which is required for the viability of the parasite.

In L. donovani there are two different enzymes that synthesize FPP and GGPP. In that way, it is possible to assume that should be more difficult to identify compounds that inhibit Pf FPPS/GGPPS and the leishmanial enzyme. The fact that most active compounds on the kinetoplastid parasite did not have hydroxy groups on their structure and were 5 times less active than the most potent (1) 
and $\mathbf{1 h} \mathrm{L}$. donovani IC $\mathrm{C}_{50}=11 \mu \mathrm{M}$ vs $\mathbf{1 k}$ and $\mathbf{1 h} 56.0$ and $48.3 \mu \mathrm{M}$, respectively) would make us think that inhibition of an isoprene enzyme was not involved in this case. Nevertheless, a complete study of the mechanism of action should be required to confirm those hypotheses.

Finally, to identify candidates with wide-spectrum activity, in this case they should have similar potency as antimalarial and antileishmanial drugs. As is clearly seen on Fig. 7 heatmap, in general the activity hot spots are different for each parasite. Nevertheless, there are 4 analogs $(\mathbf{1 g}, \mathbf{1 0}, \mathbf{1 r}$ and $\mathbf{9 a})$ that seems to be the most adequate starting point for the development of malaria-visceral leishmaniasis co-infection treatments.

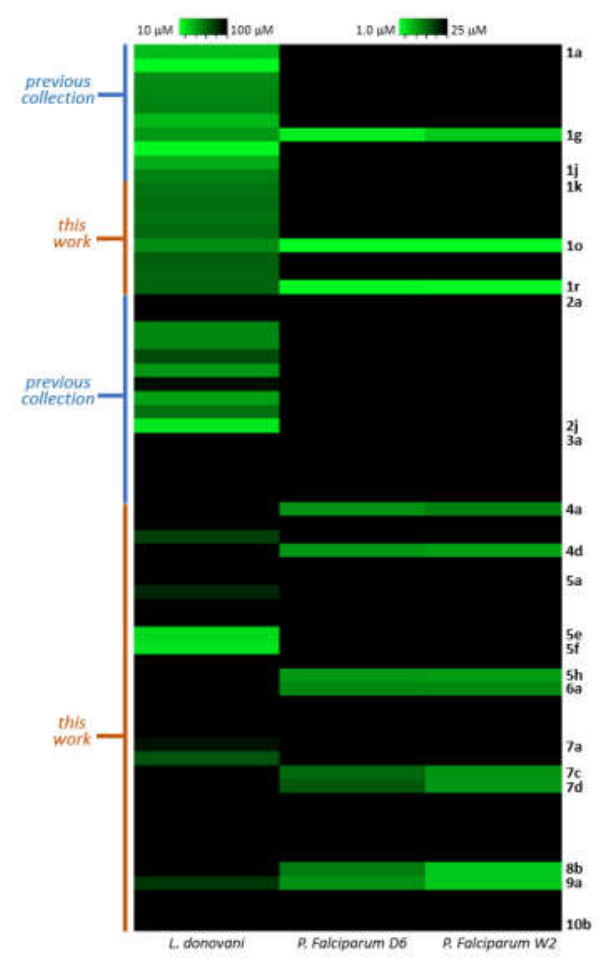

Fig. 7. P. falciparum and L. donovani activities heat map.

\subsection{Cheminformatics Analysis}

As was mentioned, FPPS is an important target for numerous pathologies and infectious diseases, therefore many inhibitors have been previously reported. Taking advantage of the ChEMBL database, a chemical database of bioactive molecules maintained by the European Bioinformatics Institute (EMBL-EBI), ${ }^{46}$ a complete search was performed that provided 470 compounds with reported activity on the enzyme. To determine the chemical space explored by the reported FPPS inhibitors, the compounds from ChemBL database were first manually depurated leading to 235 compounds. Then, the similarity of those compounds, combined with the 64 analogs evaluated as antimalarials, was analysed on the web-based platform Chemmine Tools. ${ }^{47}$ (Tanimoto coefficient $>0.7$ ) The results were plotted in a 3D scatter plot and were grouped according to the different clusters found. The 1,2,3-triazoles were also included in the same analysis to identify their similarity with the reported inhibitors. Fig. $\mathbf{8}$ shows the clusters as distinct colours dots. The white, light blue, and blue clusters belong to previously reported inhibitors found on ChemBL, while the orange are 1,2,3triazol derivatives. The analysis performed demonstrates that the prepared collection has low similarity with previously reported compounds and is a new chemotype that is in unexplored section of the chemical space of the FPPS inhibitors.

\subsection{Physicochemical parameters}

There is consensus that oral administration is the most convenient, cost-effective, and commonly used medication administration route. Therefore, it is critical over the development process of new chemical entities to consider their pharmacokinetic properties, particularly their administration, distribution, metabolization, excretion and potential toxicity properties (ADME/Tox). Achieving the best bioavailability of drugs depends on tuning these properties by structural modification. Compounds that have promissory activities but have poor bioavailability are neglected. It has been reported that a $90 \%$ attrition rate of drug candidates on the transition from preclinical trials to marketing surveillance trials because of their poor physicochemical properties. ${ }^{48}$ 


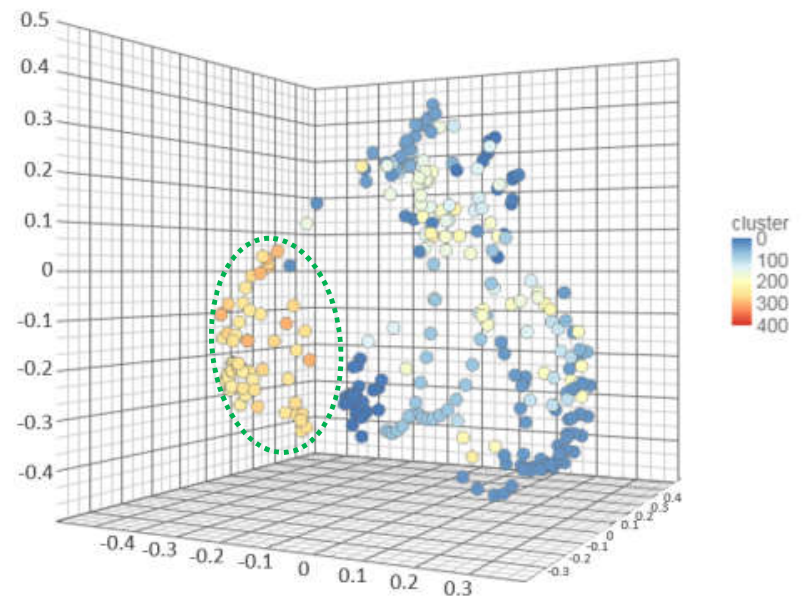

Fig. 8. Analysis of molecular similarity of the FPPS inhibitors stored on ChemBL and the 1,2,3-triazoles reported here (circled on dotted green line). The high similarity areas are clearly delimited.

There are some rules or numerical cut-offs to label a molecule as a good candidate in terms of its physicochemical properties. Considering those proposed by Lipinsky (1997), named the rules of five and other contribution like Veber's (2002), we explored our full collection of 64 synthesized molecules, and predicted their physicochemical properties computationally. To do that, we used free web services Osiris, ${ }^{49}$ and Molinspiration. ${ }^{50}$ Detailed conditions of the calculations could be found on their respective websites. Accordingly, to the Lipinsky's rules a potential drug candidate should be orally active if their molecular weight $<500 \mathrm{Da}$, logP $<5$, the number of hydrogen bond acceptors $<10$ and the number of hydrogen bond donors $<5$. Additionally, Veber's rules propose a potential orally absorbable drug candidate to those with the number of rotatable bonds $<10$ and a total polar surface area (TPSA) $<140 \AA^{2}$. These criteria could be used as a guide to select candidates to develop drugs but they are not exclusive. Compounds that violate only one of the cited rules, are still considered as good drug candidate.

Computational predictions of the physicochemical properties of the whole collection using DataWarrior shown few exceptions of the rules. (Table 3$)$ The library satisfies the restriction of $\mathrm{MW}(179-386 \mathrm{Da})$, number of $\mathrm{H}$-bond donors $(0$ or 1$)$ and acceptors $(3$ to 7). However, 22 of the 64 compounds had cLogP $>5$ (-0.39 to 8.77). Analysing the parameters for the antimalarial active compounds we could identify narrower intervals. While the number of bond donors and acceptors remain the same, the MW ranged from 195$344 \mathrm{Da}$. In contrast, the cLogP of the active compounds was narrower but still have a broad window $(-0.39-7.40)$. Interestingly the 3 more active compounds (1g, 10 y $\mathbf{1 r}$ ) were also the more lipophilic, been active even violating one of the rules of five.

Table 3. In silico physiochemical parameters of reported library.

\begin{tabular}{|c|c|c|c|c|c|c|c|}
\hline & MW & $\log P$ & $\mathbf{N}$ & nONH & TPSA & ROT & Viol \\
\hline Lipinski $^{51}$ & $<500$ & $\leq 5$ & $<10$ & $<5$ & & & 0 \\
\hline Veber $^{52}$ & & & & & $\leq 140$ & $\leq 10$ & 0 \\
\hline Library & $179-386$ & $-0.40-8.77$ & $3-7$ & $0-1$ & $30.72-83.33$ & $3-15$ & $0-1$ \\
\hline Act. Cmpds & $179-343$ & $-0.39-7.41$ & $3-7$ & $0-1$ & $30.72-83.33$ & $4-12$ & $0-1$ \\
\hline Chloroquine & 320 & 5 & 3 & 1 & 28.16 & 8 & 0 \\
\hline Artemisinin & 282 & 2.26 & 0 & 0 & 54.01 & 0 & 0 \\
\hline
\end{tabular}

Osiris platform provided the toxicity risk, drug likeness and a drug score. The results revealed that all the compounds do not have any toxicity risk, undesired effects; tumorigenic features or effect on the reproductive system. The solubility is a critical property which aids in the circulation of a drug after the administration and into the bloodstream. More than $80 \%$ of marketed drugs have $\log S>4$.

Table 4. In silico toxicity risks and drugs-score of the complete library and first line drugs.

\begin{tabular}{|c|c|c|c|c|c|c|}
\hline & \multicolumn{4}{|c|}{ Toxicity risk $^{\mathrm{a}}$} & \multicolumn{2}{|c|}{ Drug-score } \\
\hline & $M^{b}$ & $T^{c}$ & $I^{d}$ & $\operatorname{Re}^{e}$ & Drug likeness & Drug-score \\
\hline Library & - & - & - & - & $-25.40-14.35$ & $0.17-0.63$ \\
\hline Active Compounds & - & - & - & - & $-21.86-14.35$ & $0.22-0.49$ \\
\hline Chloroquine & + & - & + & - & 7.39 & 0.25 \\
\hline Artemisinin & - & + & + & - & -1.97 & 0.17 \\
\hline
\end{tabular}

${ }^{\mathrm{a}}$ Ranked according to: (-) not toxic, ( \pm ) slightly toxic, (+) highly toxic.

${ }^{\mathrm{b}} \mathrm{M}=$ mutagenic; ${ }^{\mathrm{C}} \mathrm{T}=$ tumorigenic; ${ }^{\mathrm{d}} \mathrm{I}=$ irritant; ${ }^{\mathrm{e}} \mathrm{Re}=$ reproductive effective.

Osiris platform estimates the solubility in mol/liter, where our displayed a promising range of -4.91 to -0.72 . In terms of drug 
likeness, the prepared collection shown a poor profile (-25.4 to 14.35) compared to commercial drugs like chloroquine or artemisinin (7.39 and -1.975, respectively). That poor behaviour is balanced with the rest of the parameters used to calculate the drug score (solubility, logP, MW and toxicity risk) delivering moderate to good values ( 0.17 to 0.63 ) compared with standard drugs ( 0.17 to 0.25$)$. A detailed analysis of compounds 10 and $\mathbf{1 r}$ shown that have a very good drug score $(0.33$ and 0.30$)$ compared with chloroquine (0.25), and also share very similar physicochemical properties Table 5. Considering that both compounds have almost the same antiplasmodial potency, it promotes the selection of these candidates for future studies.

Table 5. In silico parameters and biological activities of farnesylated hits

\begin{tabular}{|c|c|c|c|c|c|c|c|c|c|}
\hline ID & $\begin{array}{c}\text { Toxicity } \\
\text { risks }\end{array}$ & MW & $\log P$ & PSA & $\begin{array}{l}\text { Drug- } \\
\text { score }\end{array}$ & $\begin{array}{c}\text { P.f. D6 } \\
\mathrm{IC}_{50} \mu \mathrm{M}^{\mathrm{a}}\end{array}$ & $S I^{c}$ & $\begin{array}{l}\text { P. f. W2 } \\
\mathrm{IC}_{50} \mu \mathrm{M}^{\mathrm{b}}\end{array}$ & $\mathrm{SI}^{\mathrm{c}}$ \\
\hline 10 & $\cdots$ & 332 & 5.56 & 50.95 & 0.30 & 2.35 & 6.09 & 1.99 & 7.20 \\
\hline $1 r$ & - . - & 318 & 5.12 & 50.95 & 0.33 & 2.74 & 5.46 & 2.05 & 7.31 \\
\hline
\end{tabular}

${ }^{\mathrm{a}}$ Activity against $P$. falciparum $D 6,{ }^{\mathrm{b}}$ Activity against $P$. falciparum $\mathrm{W} 2,{ }^{\mathrm{c}}$ Selectivity index calculated.

\section{Experimental}

\subsection{General}

${ }^{1} \mathrm{H}$ and ${ }^{13} \mathrm{C}$ NMR spectra were acquired on a Bruker Avance II $300 \mathrm{MHz}(75.13 \mathrm{MHz})$ using $\mathrm{CDCl}_{3}$ as solvent. Chemical shifts $(\delta)$ were reported in ppm downfield from tetramethylsilane (TMS) at 0 ppm as internal standard and coupling constants $(J)$ are in hertz (Hz). Chemical shifts for carbon nuclear magnetic resonance $\left({ }^{13} \mathrm{C} \mathrm{NMR}\right)$ spectra are reported in parts per million relatives to the center line of the $\mathrm{CDCl}_{3}$ triplet at $76.9 \mathrm{ppm}$. The following abbreviations are used to indicate NMR signal multiplicities: $\mathrm{s}=$ singlet, $d=$ doublet, $\mathrm{t}=$ triplet, $\mathrm{q}=$ quartet, $\mathrm{m}=$ multiplet, $\mathrm{p}=$ pentet, $\mathrm{br}=$ broad signal. High-resolution mass spectra (HRMS) were recorded on a Bruker MicroTOF II with lock spray source. Chemical reagents were purchased from commercial suppliers and used without further purification, unless otherwise noted. Solvents were analytical grade or were purified by standard procedures prior to use. Yields were calculated for material judged homogeneous by thin layer chromatography (TLC) and nuclear magnetic resonance $\left({ }^{1} \mathrm{H}\right.$ NMR). All reactions were monitored by thin layer chromatography performed on silica gel $60 F_{254}$ pre-coated aluminium sheets, visualized by a $254 \mathrm{~nm}$ UV lamp, and stained with an ethanolic solution of 4-anisaldehyde. Column flash chromatography was performed using silica gel 60 (230-400 mesh).

\subsection{Synthesis}

General procedure for the $\mathrm{Cu}(\mathrm{l})$ mediated 1,3-dipolar cycloaddition

Alkyne (1 eq) and the azide (1.1 eq) were suspended in $10 \mathrm{~mL} /$ eq of $t \mathrm{BuOH}: \mathrm{H}_{2} \mathrm{O}(1: 1)$ and then $1 \mathrm{M} \mathrm{CuSO}_{4}$ solution and finally $1 \mathrm{M}$ sodium ascorbate solution were added, and the mixture was stirred overnight at room temperature. Brine was added, and the solution was extracted with dichloromethane. Combined organic extracts were dried over sodium sulphate and evaporated. Products were purified by column chromatography in silica gel with increasing hexane/ethyl acetate or ethyl acetate/ethanol gradients.

Synthesis of (1-((2Z,6E)-3,7,11-trimethyldodeca-2,6,10-trien-1-yl)-1H-1,2,3-triazol-4-yl)methanol (1k)

Colorless oil. ${ }^{1} \mathrm{H}-\mathrm{NMR}\left(300 \mathrm{MHz}, \mathrm{CDCl}_{3}\right): \delta 7.48(\mathrm{~s}, 1 \mathrm{H}), 5.43(\mathrm{t}, J=7.3 \mathrm{~Hz}, 1 \mathrm{H}), 5.07(\mathrm{q}, J=4.1 \mathrm{~Hz}, 2 \mathrm{H}), 4.96(\mathrm{~d}, J=7.3 \mathrm{~Hz}, 2 \mathrm{H}), 4.77(\mathrm{~s}$, 2H), 2.12- $1.97(8 \mathrm{H}), 1.78(\mathrm{~s}, 3 \mathrm{H}), 1.67(\mathrm{~s}, 3 \mathrm{H}), 1.59(\mathrm{~s}, 6 \mathrm{H}) .{ }^{13} \mathrm{C} \mathrm{NMR}\left(75 \mathrm{MHz}, \mathrm{CDCl}_{3}\right): \delta 147.9$ (C), 143.4 (C), 135.7 (C), $131.4(\mathrm{C})$, 124.2 (CH), $123.3(\mathrm{CH}), 121.2(\mathrm{CH}), 116.9(\mathrm{CH}), 56.0\left(\mathrm{CH}_{2}\right), 47.9\left(\mathrm{CH}_{2}\right), 39.6\left(\mathrm{CH}_{2}\right), 39.4\left(\mathrm{CH}_{2}\right), 26.6\left(\mathrm{CH}_{2}\right), 26.1\left(\mathrm{CH}_{2}\right), 25.7\left(\mathrm{CH}_{3}\right), 17.7$ $\left(\mathrm{CH}_{3}\right), 16.5\left(\mathrm{CH}_{3}\right), 16.0\left(\mathrm{CH}_{3}\right)$. ESI-HRMS Calcd. for $\left(\mathrm{M}+\mathrm{H}^{+}\right) \mathrm{C}_{18} \mathrm{H}_{30} \mathrm{~N}_{3} \mathrm{O} 304.2389$, found 304.2393.

Synthesis of (1-((2E,6E)-3,7,11-trimethyldodeca-2,6,10-trien-1-yl)-1H-1,2,3-triazol-4-yl)methanol (11) Colorless oil. ${ }^{1} \mathrm{H}-\mathrm{NMR}\left(300 \mathrm{MHz}, \mathrm{CDCl}_{3}\right): \delta 7.49(\mathrm{~s}, 1 \mathrm{H}), 5.42(\mathrm{t}, J=7.2 \mathrm{~Hz}, 1 \mathrm{H}), 5.08(\mathrm{q}, J=6.8 \mathrm{~Hz}, 2 \mathrm{H}), 4.95(\mathrm{~s}, 1 \mathrm{H}), 4.93(\mathrm{~s}, 1 \mathrm{H}), 4.77$ $(\mathrm{s}, 2 \mathrm{H}), 2.20-1.97(8 \mathrm{H}), 1.81(\mathrm{~s}, 3 \mathrm{H}), 1.67(\mathrm{~s}, 3 \mathrm{H}), 1.61(\mathrm{~s}, 3 \mathrm{H}), 1.59(\mathrm{~s}, 3 \mathrm{H}) .{ }^{13} \mathrm{C} \mathrm{NMR}\left(75 \mathrm{MHz}, \mathrm{CDCl}_{3}\right): \delta 147.9$ (C), $143.3(\mathrm{C}), 136.3(\mathrm{C})$, $131.5(\mathrm{C}), 124.1(\mathrm{CH}), 123.0(\mathrm{CH}), 121.2(\mathrm{CH}), 117.7(\mathrm{CH}), 56.1\left(\mathrm{CH}_{2}\right), 47.7\left(\mathrm{CH}_{2}\right), 39.7\left(\mathrm{CH}_{2}\right), 32.1\left(\mathrm{CH}_{2}\right), 26.6\left(\mathrm{CH}_{2}\right), 26.3\left(\mathrm{CH}_{2}\right), 25.7$ $\left(\mathrm{CH}_{3}\right), 23.4\left(\mathrm{CH}_{3}\right), 17.7\left(\mathrm{CH}_{3}\right), 16.0\left(\mathrm{CH}_{3}\right)$. ESI-HRMS Calcd. for $\left(\mathrm{M}+\mathrm{H}^{+}\right) \mathrm{C}_{18} \mathrm{H}_{30} \mathrm{~N}_{3} \mathrm{O} 304.2389$, found 304.2397.

Synthesis of 1-(1-((2Z,6E)-3,7,11-trimethyldodeca-2,6,10-trien-1-yl)-1H-1,2,3-triazol-4-yl)ethanol (1m)

Colorless oil. ${ }^{1} \mathrm{H}-\mathrm{NMR}\left(300 \mathrm{MHz}, \mathrm{CDCl}_{3}\right): \delta 7.41(\mathrm{~s}, 1 \mathrm{H}), 5.43(\mathrm{t}, J=7.4 \mathrm{~Hz}, 1 \mathrm{H}), 5.07(\mathrm{~m}, J=6.0 \mathrm{~Hz}, 3 \mathrm{H}), 4.95(\mathrm{~d}, J=7.4 \mathrm{~Hz}, 2 \mathrm{H}), 2.13-$ $1.97(\mathrm{~m}, 8 \mathrm{H}), 1.79(\mathrm{~s}, 3 \mathrm{H}), 1.67(\mathrm{~s}, 3 \mathrm{H}), 1.63(\mathrm{~s}, 3 \mathrm{H}), 1.59(\mathrm{~s}, 6 \mathrm{H}) .{ }^{13} \mathrm{C} \mathrm{NMR}\left(75 \mathrm{MHz}, \mathrm{CDCl}_{3}\right): \delta 152.5(\mathrm{C}), 143.2(\mathrm{C}), 135.8(\mathrm{C}), 131.4(\mathrm{C})$, 124.2 (CH), $123.3(\mathrm{CH}), 119.4(\mathrm{CH}), 116.9(\mathrm{CH}), 62.9(\mathrm{CH}), 47.9\left(\mathrm{CH}_{2}\right), 39.7\left(\mathrm{CH}_{2}\right), 39.4\left(\mathrm{CH}_{2}\right), 26.7\left(\mathrm{CH}_{2}\right), 26.0\left(\mathrm{CH}_{2}\right), 25.7\left(\mathrm{CH}_{3}\right), 23.1$ $\left(\mathrm{CH}_{3}\right), 17.7\left(\mathrm{CH}_{3}\right), 16.5\left(\mathrm{CH}_{3}\right), 16.0\left(\mathrm{CH}_{3}\right)$. ESI-HRMS Calcd. for $\left(\mathrm{M}+\mathrm{H}^{+}\right) \mathrm{C}_{19} \mathrm{H}_{32} \mathrm{~N}_{3} \mathrm{O} 318.2545$, found 318.2556.

Synthesis of 1-(1-((2E,6E)-3,7,11-trimethyldodeca-2,6,10-trien-1-yl)-1H-1,2,3-triazol-4-yl)ethanol (1n)

Colorless oil. ${ }^{1} \mathrm{H}-\mathrm{NMR}\left(\mathbf{3 0 0} \mathbf{M H z}, \mathrm{CDCl}_{3}\right): \delta 7.42(\mathrm{~s}, 1 \mathrm{H}), 5.42(\mathrm{t}, J=7.5 \mathrm{~Hz}, 1 \mathrm{H}), 5.08(\mathrm{~m}, J=3.7 \mathrm{~Hz}, 3 \mathrm{H}), 4.93(\mathrm{~d}, J=7.3 \mathrm{~Hz}, 2 \mathrm{H}), 2.21-$ $1.98(8 \mathrm{H}), 1.81(\mathrm{~s}, 3 \mathrm{H}), 1.67(\mathrm{~s}, 6 \mathrm{H}), 1.61(\mathrm{~s}, 3 \mathrm{H}), 1.59(\mathrm{~s}, 3 \mathrm{H}) .{ }^{13} \mathrm{C} \mathrm{NMR}\left(\mathbf{7 5} \mathrm{MHz}, \mathrm{CDCl}_{3}\right): \delta 152.4(\mathrm{C}), 143.2(\mathrm{C}), 136.3(\mathrm{C}), 131.5(\mathrm{C})$, 
124.1 (CH), $123.0(\mathrm{CH}), 119.3(\mathrm{CH}), 117.7(\mathrm{CH}), 63.0(\mathrm{CH}), 47.7\left(\mathrm{CH}_{2}\right), 39.7\left(\mathrm{CH}_{2}\right), 32.1\left(\mathrm{CH}_{2}\right), 26.6\left(\mathrm{CH}_{2}\right), 26.3\left(\mathrm{CH}_{2}\right), 25.7\left(\mathrm{CH}_{3}\right), 23.4$ $\left(\mathrm{CH}_{3}\right), 23.1\left(\mathrm{CH}_{3}\right), 17.7\left(\mathrm{CH}_{3}\right), 16.0\left(\mathrm{CH}_{3}\right)$. ESI-HRMS Calcd. for $\left(\mathrm{M}+\mathrm{H}^{+}\right) \mathrm{C}_{19} \mathrm{H}_{32} \mathrm{~N}_{3} \mathrm{O} 318.2545$, found 318.2545.

Synthesis of 2-(1-((2Z,6E)-3,7,11-trimethyldodeca-2,6,10-trien-1-yl)-1H-1,2,3-triazol-4-yl)propan-2-ol (10)

Colorless oil. ${ }^{1} \mathrm{H}$-NMR (300 MHz, CDCl $)$ ): $\delta 7.37(\mathrm{~s}, 1 \mathrm{H}), 5.43(\mathrm{t}, J=7.5 \mathrm{~Hz}, 1 \mathrm{H}), 5.07(\mathrm{p}, J=6.2 \mathrm{~Hz}, 2 \mathrm{H}), 4.95(\mathrm{~d}, J=7.3 \mathrm{~Hz}, 2 \mathrm{H}), 2.13-$ $1.97(\mathrm{~m}, 8 \mathrm{H}), 1.79(\mathrm{~s}, 3 \mathrm{H}), 1.67(\mathrm{~s}, 3 \mathrm{H}), 1.63(\mathrm{~s}, 6 \mathrm{H}), 1.59(\mathrm{~s}, 6 \mathrm{H}) .{ }^{13} \mathrm{C} \mathrm{NMR}\left(75 \mathrm{MHz}, \mathrm{CDCl}_{3}\right): \delta 155.7(\mathrm{C}), 143.0(\mathrm{C}), 135.7(\mathrm{C}), 131.3(\mathrm{C})$, $124.2(\mathrm{CH}), 123.3(\mathrm{CH}), 118.5(\mathrm{CH}), 117.0(\mathrm{CH}), 68.4(\mathrm{C}), 47.8\left(\mathrm{CH}_{2}\right), 39.6\left(\mathrm{CH}_{2}\right), 39.4\left(\mathrm{CH}_{2}\right), 30.4\left(\mathrm{CH}_{3}\right), 26.6\left(\mathrm{CH}_{2}\right), 26.0\left(\mathrm{CH}_{2}\right), 25.7$ $\left(\mathrm{CH}_{2}\right), 17.7\left(\mathrm{CH}_{3}\right), 16.5\left(\mathrm{CH}_{3}\right), 16.0\left(\mathrm{CH}_{3}\right)$. ESI-HRMS Calcd. for $\left(\mathrm{M}+\mathrm{H}^{+}\right) \mathrm{C}_{20} \mathrm{H}_{34} \mathrm{~N}_{3} \mathrm{O} 332.2702$, found 332.2701.

Synthesis of 2-(1-((2E,6E)-3,7,11-trimethyldodeca-2,6,10-trien-1-yl)-1H-1,2,3-triazol-4-yl)propan-2-ol (1p)

Colorless oil. ${ }^{1} \mathrm{H}-\mathrm{NMR}\left(300 \mathrm{MHz}, \mathrm{CDCl}_{3}\right): \delta 7.38(\mathrm{~s}, 1 \mathrm{H}), 5.43(\mathrm{t}, J=7.5 \mathrm{~Hz}, 1 \mathrm{H}), 5.09(\mathrm{p}, J=6.2 \mathrm{~Hz}, 2 \mathrm{H}), 4.93(\mathrm{~d}, J=7.3 \mathrm{~Hz}, 2 \mathrm{H}), 2.13-$ $1.97(\mathrm{~m}, 8 \mathrm{H}), 1.79(\mathrm{~s}, 3 \mathrm{H}), 1.67(\mathrm{~s}, 3 \mathrm{H}), 1.63(\mathrm{~s}, 3 \mathrm{H}), 1.59(\mathrm{~s}, 6 \mathrm{H}) .{ }^{13} \mathrm{C} \mathrm{NMR}\left(75 \mathrm{MHz}, \mathrm{CDCl}_{3}\right): \delta 155.6(\mathrm{C}), 143.1(\mathrm{C}), 136.3(\mathrm{C}), 131.5(\mathrm{C})$, $124.1(\mathrm{CH}), 123.0(\mathrm{CH}), 118.4(\mathrm{CH}), 117.8(\mathrm{CH}), 68.5(\mathrm{C}), 47.7\left(\mathrm{CH}_{2}\right), 39.7\left(\mathrm{CH}_{2}\right), 32.1\left(\mathrm{CH}_{2}\right), 30.5\left(\mathrm{CH}_{3}\right), 26.6\left(\mathrm{CH}_{2}\right), 26.3\left(\mathrm{CH}_{2}\right), 25.7$ $\left(\mathrm{CH}_{2}\right), 23.4\left(\mathrm{CH}_{3}\right), 17.7\left(\mathrm{CH}_{3}\right), 16.0\left(\mathrm{CH}_{3}\right)$. ESI-HRMS Calcd. for $\left(\mathrm{M}+\mathrm{H}^{+}\right) \mathrm{C}_{20} \mathrm{H}_{34} \mathrm{~N}_{3} \mathrm{O} 332.2702$, found 332.2716.

Synthesis of 2-(1-((2Z,6E)-3,7,11-trimethyldodeca-2,6,10-trien-1-yl)-1H-1,2,3-triazol-4-yl)ethanol (1q)

Colorless oil. ${ }^{1} \mathrm{H}-\mathrm{NMR}\left(300 \mathrm{MHz}, \mathrm{CDCl}_{3}\right): \delta 7.33(\mathrm{~s}, 1 \mathrm{H}), 5.43(\mathrm{t}, J=7.4 \mathrm{~Hz}, 1 \mathrm{H}), 5.08(\mathrm{t}, J=5.1 \mathrm{~Hz}, 2 \mathrm{H}), 4.94(\mathrm{~d}, J=7.2 \mathrm{~Hz}, 2 \mathrm{H}), 3.95(\mathrm{t}$, $J=5.9 \mathrm{~Hz}, 2 \mathrm{H}), 2.93(\mathrm{t}, J=5.9 \mathrm{~Hz}, 2 \mathrm{H}), 2.12-1.97(8 \mathrm{H}), 1.78(\mathrm{~s}, 3 \mathrm{H}), 1.67(\mathrm{~s}, 3 \mathrm{H}), 1.59(\mathrm{~s}, 6 \mathrm{H}) .{ }^{13} \mathrm{C} \mathrm{NMR}\left(75 \mathrm{MHz}, \mathrm{CDCl}_{3}\right): \delta 145.5(\mathrm{C})$, $143.2(\mathrm{C}), 135.8(\mathrm{C}), 131.4(\mathrm{C}), 124.2(\mathrm{CH}), 123.3\left(\mathrm{CH}_{2}\right), 120.9(\mathrm{CH}), 117.0(\mathrm{CH}), 61.6\left(\mathrm{CH}_{2}\right), 47.8\left(\mathrm{CH}_{2}\right), 39.7\left(\mathrm{CH}_{2}\right), 39.4\left(\mathrm{CH}_{2}\right), 28.7$ $\left(\mathrm{CH}_{2}\right), 26.7\left(\mathrm{CH}_{2}\right), 26.0\left(\mathrm{CH}_{2}\right), 25.7\left(\mathrm{CH}_{3}\right), 17.7\left(\mathrm{CH}_{3}\right), 16.5\left(\mathrm{CH}_{3}\right), 16.0\left(\mathrm{CH}_{3}\right)$. ESI-HRMS Calcd. for $\left(\mathrm{M}+\mathrm{H}^{+}\right) \mathrm{C}_{19} \mathrm{H}_{32} \mathrm{~N}_{3} \mathrm{O} 318.2545$, found 318.2544

Synthesis of 2-(1-((2E,6E)-3,7,11-trimethyldodeca-2,6,10-trien-1-yl)-1H-1,2,3-triazol-4-yl)ethanol (1r)

Colorless oil. ${ }^{1} \mathrm{H}-\mathrm{NMR}\left(300 \mathrm{MHz}, \mathrm{CDCl}_{3}\right): \delta 7.33(\mathrm{~s}, 1 \mathrm{H}), 5.40(\mathrm{t}, J=7.3 \mathrm{~Hz}, 1 \mathrm{H}), 5.06(\mathrm{t}, J=6.6 \mathrm{~Hz}, 2 \mathrm{H}), 4.92(\mathrm{~d}, J=7.3 \mathrm{~Hz}, 2 \mathrm{H}), 3.91(\mathrm{t}$, $J=5.9 \mathrm{~Hz}, 2 \mathrm{H}), 2.91(\mathrm{t}, J=5.9 \mathrm{~Hz}, 2 \mathrm{H}), 2.17-1.93(8 \mathrm{H}), 1.76(\mathrm{~s}, 3 \mathrm{H}), 1.65(\mathrm{~s}, 3 \mathrm{H}), 1.58(\mathrm{~s}, 6 \mathrm{H}) .{ }^{13} \mathrm{C} \mathrm{NMR}\left(75 \mathrm{MHz}, \mathrm{CDCl}_{3}\right): \delta 145.5(\mathrm{C})$, $143.2(\mathrm{C}), 135.8(\mathrm{C}), 131.4(\mathrm{C}), 124.2(\mathrm{CH}), 123.3\left(\mathrm{CH}_{2}\right), 120.9(\mathrm{CH}), 117.0(\mathrm{CH}), 61.6\left(\mathrm{CH}_{2}\right), 47.8\left(\mathrm{CH}_{2}\right), 39.7\left(\mathrm{CH}_{2}\right), 39.4\left(\mathrm{CH}_{2}\right), 28.7$ $\left(\mathrm{CH}_{2}\right), 26.7\left(\mathrm{CH}_{2}\right), 26.0\left(\mathrm{CH}_{2}\right), 25.7\left(\mathrm{CH}_{3}\right), 17.7\left(\mathrm{CH}_{3}\right), 16.5\left(\mathrm{CH}_{3}\right), 16.0\left(\mathrm{CH}_{3}\right)$. ESI-HRMS Calcd. for $\left(\mathrm{M}+\mathrm{H}^{+}\right) \mathrm{C}_{19} \mathrm{H}_{32} \mathrm{~N}_{3} \mathrm{O} 318.2545$, found 318.2561 .

Synthesis of 1-cinnamyl-4-phenyl-1H-1,2,3-triazole (4a)

Colorless solid. ${ }^{1} \mathrm{H}-\mathrm{NMR}\left(300 \mathrm{MHz}, \mathrm{CDCl}_{3}\right): \delta 7.86-7.81(3 \mathrm{H}), 7.44-7.29(8 \mathrm{H}), 6.79(\mathrm{~d}, J=15.9 \mathrm{~Hz}, 1 \mathrm{H}), 6.37\left(\mathrm{dt}, J_{1}=15.9 \mathrm{~Hz}, J_{2}=6.5\right.$ $\mathrm{Hz}, 1 \mathrm{H}), 5.15(\mathrm{~d}, J=6.7 \mathrm{~Hz}, 2 \mathrm{H}) .{ }^{13} \mathrm{C} \mathrm{NMR}\left(75 \mathrm{MHz}, \mathrm{CDCl}_{3}\right)$ : $\delta 148.1(\mathrm{C}), 135.5(\mathrm{C}), 135.4(\mathrm{CH}), 130.6(\mathrm{C}), 128.9(\mathrm{CH}), 128.8(\mathrm{CH}), 128.6$ $(\mathrm{CH}), 128.2(\mathrm{CH}), 126.8(\mathrm{CH}), 125.7(\mathrm{CH}), 122.0(\mathrm{CH}), 119.5(\mathrm{CH}), 52.4\left(\mathrm{CH}_{2}\right)$. ESI-HRMS Calcd. for $\left(\mathrm{M}^{+} \mathrm{H}^{+}\right) \mathrm{C}_{17} \mathrm{H}_{16} \mathrm{~N}_{3} 262.1339$, found 262.1344 .

Synthesis of 1-cinnamyl-4-propyl-1H-1,2,3-triazole (4b)

Colorless solid m.p. $44.0-44.7^{\circ} \mathrm{C} .{ }^{1} \mathrm{H}-\mathrm{NMR}\left(300 \mathrm{MHz}, \mathrm{CDCl}_{3}\right): \delta 7.39-7.27(6 \mathrm{H}), 6.64(\mathrm{~d}, J=15.9 \mathrm{~Hz}, 1 \mathrm{H}), 6.34\left(\mathrm{dt}, J_{1}=15.9 \mathrm{~Hz}, J_{2}=6.5\right.$ $\left.\mathrm{Hz}, 1 \mathrm{H}), 5.09(\mathrm{~d}, J=6.6 \mathrm{~Hz}, 2 \mathrm{H}), 2.70(\mathrm{t}, J=7.6 \mathrm{~Hz}, 2 \mathrm{H}), 1.71(\mathrm{~m}, 2 \mathrm{H}), 0.96(\mathrm{t}, J=7.3 \mathrm{~Hz}, 3 \mathrm{H}) .{ }^{13} \mathrm{C} \mathrm{NMR}(75 \mathrm{MHz}, \mathrm{CDCl})_{3}\right): \delta 148.6(\mathrm{C})$, $135.6(\mathrm{C}), 134.9(\mathrm{CH}), 128.7(\mathrm{CH}), 128.4(\mathrm{CH}), 126.7(\mathrm{CH}), 122.3(\mathrm{CH}), 120.4(\mathrm{CH}), 52.1\left(\mathrm{CH}_{2}\right), 27.7\left(\mathrm{CH}_{2}\right), 22.7\left(\mathrm{CH}_{2}\right), 13.8\left(\mathrm{CH}_{3}\right) . \mathrm{ESI}-$ HRMS Calcd. for $\left(\mathrm{M}+\mathrm{H}^{+}\right) \mathrm{C}_{14} \mathrm{H}_{18} \mathrm{~N}_{3} 228.1501$, found 228.1495 .

Synthesis of 1-cinnamyl-4-pentyl-1H-1,2,3-triazole (4c)

Colorless solid m.p. 54.1- $54.9^{\circ} \mathrm{C} .{ }^{1} \mathrm{H}-\mathrm{NMR}\left(300 \mathrm{MHz}, \mathrm{CDCl}_{3}\right): \delta 7.41-7.28(6 \mathrm{H}), 6.5(\mathrm{~d}, J=15.7 \mathrm{~Hz}, 1 \mathrm{H}), 6.34\left(\mathrm{dt}, J_{1}=15.7 \mathrm{~Hz}, J_{2}=6.5\right.$ $\mathrm{Hz}, 1 \mathrm{H}), 5.10(\mathrm{~d}, J=6.6 \mathrm{~Hz}, 2 \mathrm{H}), 1.72-1.67(2 \mathrm{H}), 1.37-1.31(\mathrm{~m}, 4 \mathrm{H}), 0.89(\mathrm{t}, J=7.0 \mathrm{~Hz}, 3 \mathrm{H}) .{ }^{13} \mathrm{C} \mathrm{NMR}\left(75 \mathrm{MHz}, \mathrm{CDCl}_{3}\right): \delta 148.8(\mathrm{C})$, $135.6(\mathrm{C}), 134.9(\mathrm{CH}), 128.7(\mathrm{CH}), 128.4(\mathrm{CH}), 126.7(\mathrm{CH}), 122.3(\mathrm{CH}), 120.4(\mathrm{CH}), 52.1\left(\mathrm{CH}_{2}\right), 31.4\left(\mathrm{CH}_{2}\right), 29.2\left(\mathrm{CH}_{2}\right), 25.7\left(\mathrm{CH}_{2}\right), 22.4$ $\left(\mathrm{CH}_{2}\right), 14.0\left(\mathrm{CH}_{3}\right)$. ESI-HRMS Calcd. for $\left(\mathrm{M}+\mathrm{H}^{+}\right) \mathrm{C}_{16} \mathrm{H}_{22} \mathrm{~N}_{3} 256.1814$, found 256.1803.

Synthesis of 1-cinnamyl-4-octyl-1H-1,2,3-triazole (4d)

Colorless solid. ${ }^{1} \mathrm{H}-\mathrm{NMR}\left(\mathbf{3 0 0} \mathbf{M H z}, \mathrm{CDCl}_{3}\right): \delta 7.40-7.28(6 \mathrm{H}), 7.65(\mathrm{~d}, \mathrm{~J}=16.0 \mathrm{~Hz}, 1 \mathrm{H}), 6.34\left(\mathrm{dt}, \mathrm{J}_{1}=16.0 \mathrm{~Hz}, \mathrm{~J}_{2}=6.7 \mathrm{~Hz}, 1 \mathrm{H}\right), 5.10(\mathrm{~d}, J$ $=6.6 \mathrm{~Hz}, 2 \mathrm{H}), 2.71(\mathrm{t}, J=7.6 \mathrm{~Hz}, 2 \mathrm{H}), 1.71-1.61(2 \mathrm{H}), 1.32-1.26(10 \mathrm{H}), 0.87(\mathrm{t}, J=6.5 \mathrm{~Hz}, 3 \mathrm{H}) .{ }^{13} \mathrm{C} \mathrm{NMR}\left(75 \mathrm{MHz}, \mathrm{CDCl}_{3}\right): \delta 135.6(\mathrm{C})$, $135.0(\mathrm{CH}), 128.7(\mathrm{CH}), 128.5(\mathrm{CH}), 126.7(\mathrm{CH}), 122.3(\mathrm{CH}), 120.3(\mathrm{CH}), 52.2\left(\mathrm{CH}_{2}\right), 31.8\left(\mathrm{CH}_{2}\right), 29.5\left(\mathrm{CH}_{2}\right), 29.3\left(\mathrm{CH}_{2}\right), 29.3\left(\mathrm{CH}_{2}\right), 29.2$ $\left(\mathrm{CH}_{2}\right), 25.8\left(\mathrm{CH}_{2}\right), 22.7\left(\mathrm{CH}_{2}\right), 14.1\left(\mathrm{CH}_{3}\right)$. ESI-HRMS Calcd. for $\left(\mathrm{M}+\mathrm{H}^{+}\right) \mathrm{C}_{19} \mathrm{H}_{28} \mathrm{~N}_{3}$ 298.2283, found 298.2290.

Synthesis of 1-cinnamyl-4-decyl-1H-1,2,3-triazole (4e)

Colorless solid m.p. 83.3-84.1 ${ }^{\circ} \mathrm{C} .{ }^{1} \mathrm{H}-\mathrm{NMR}\left(300 \mathrm{MHz}, \mathrm{CDCl}_{3}\right): \delta 7.41-7.28(6 \mathrm{H}), 7.65(\mathrm{~d}, \mathrm{~J}=15.8 \mathrm{~Hz}, 1 \mathrm{H}), 6.34\left(\mathrm{dt}, \mathrm{J}_{1}=15.8 \mathrm{~Hz}, \mathrm{~J}_{2}=6.6\right.$ $\mathrm{Hz}, 1 \mathrm{H}), 5.10(\mathrm{~d}, J=6.6 \mathrm{~Hz}, 2 \mathrm{H}), 2.71(\mathrm{t}, J=7.4 \mathrm{~Hz}, 2 \mathrm{H}), 1.71-1.61(2 \mathrm{H}), 1.34-1.30(14 \mathrm{H}), 0.87(\mathrm{t}, J=6.5 \mathrm{~Hz}, 3 \mathrm{H}) .{ }^{13} \mathrm{C} \mathrm{NMR}(75 \mathrm{MHz}$, $\left.\mathrm{CDCl}_{3}\right): \delta 148.8(\mathrm{C}), 135.6(\mathrm{C}), 134.9(\mathrm{CH}), 128.7(\mathrm{CH}), 128.4(\mathrm{CH}), 126.7(\mathrm{CH}), 122.4(\mathrm{CH}), 120.3(\mathrm{CH}), 52.1\left(\mathrm{CH}_{2}\right), 31.9\left(\mathrm{CH}_{2}\right), 29.6$ $\left(\mathrm{CH}_{2}\right), 29.5\left(\mathrm{CH}_{2}\right), 29.5\left(\mathrm{CH}_{2}\right), 25.4\left(\mathrm{CH}_{2}\right), 29.3\left(\mathrm{CH}_{2}\right), 25.8\left(\mathrm{CH}_{2}\right), 22.6\left(\mathrm{CH}_{2}\right), 14.1\left(\mathrm{CH}_{3}\right)$. ESI-HRMS Calcd. for $\left(\mathrm{M}+\mathrm{H}^{+}\right) \mathrm{C}_{21} \mathrm{H}_{32} \mathrm{~N}_{3}$ 326.2596 , found 326.2586 . 
Synthesis of 1-benzyl-4-decyl-1H-1,2,3-triazole (5h)

Colorless solid. ${ }^{1} \mathrm{H}-\mathrm{NMR}\left(\mathbf{3 0 0} \mathrm{MHz}, \mathrm{CDCl}_{3}\right): \delta$ 7.38-7.33 (3H), 7.26-7.23 (2H), 7.17 (s, $\left.1 \mathrm{H}\right), 5.49(\mathrm{~s}, 1 \mathrm{H}), 2.68(\mathrm{t}, \mathrm{J}=7.6 \mathrm{~Hz}, 2 \mathrm{H}), 1.67-$ $1.58(2 \mathrm{H}), 1.29-1.24(14 \mathrm{H}), 0.87(\mathrm{t}, J=6.3 \mathrm{~Hz}, 3 \mathrm{H}) .{ }^{13} \mathrm{C}$ NMR $\left(75 \mathrm{MHz}, \mathrm{CDCl}_{3}\right): \delta 149.0(\mathrm{C}), 135.0(\mathrm{C}), 129.0(\mathrm{CH}), 128.6(\mathrm{CH}), 127.9$ (CH), $120.4(\mathrm{CH}), 54.0\left(\mathrm{CH}_{2}\right), 31.9\left(\mathrm{CH}_{2}\right), 29.6\left(\mathrm{CH}_{2}\right), 29.5\left(\mathrm{CH}_{2}\right), 29.4\left(\mathrm{CH}_{2}\right), 29.3\left(\mathrm{CH}_{2}\right), 29.3\left(\mathrm{CH}_{2}\right), 29.3\left(\mathrm{CH}_{2}\right), 25.7\left(\mathrm{CH}_{2}\right), 22.7\left(\mathrm{CH}_{2}\right)$, $14.1\left(\mathrm{CH}_{3}\right)$. ESI-HRMS Calcd. for $\left(\mathrm{M}+\mathrm{H}^{+}\right) \mathrm{C}_{19} \mathrm{H}_{30} \mathrm{~N}_{3} 300.2440$, found 300.2438 .

Synthesis of Methyl 1-(2-ethoxy-2-oxoethyl)-1H-1,2,3-triazole-4-carboxylate (6a)

Colorless solid. ${ }^{1} \mathrm{H}-\mathrm{NMR}\left(300 \mathrm{MHz}, \mathrm{CDCl}_{3}\right): \delta 8.26(\mathrm{~s}, 1 \mathrm{H}), 5.22(\mathrm{~s}, 2 \mathrm{H}), 4.28(\mathrm{q}, J=7.2 \mathrm{~Hz}, 2 \mathrm{H}), 3.96(\mathrm{~s}, 3 \mathrm{H}), 1.30(\mathrm{t}, J=7.2 \mathrm{~Hz}, 3 \mathrm{H}) .{ }^{13} \mathrm{C}$ NMR (75 MHz, CDCl $)$ : $\delta 165.5(\mathrm{C}), 160.9(\mathrm{C}), 140.5(\mathrm{C}), 128.9(\mathrm{CH}), 62.8\left(\mathrm{CH}_{2}\right), 52.3\left(\mathrm{CH}_{3}\right), 51.0\left(\mathrm{CH}_{2}\right), 14.1\left(\mathrm{CH}_{3}\right)$.

Synthesis of 1-(3-phenylpropyl)-4-propyl-1H-1,2,3-triazole (7c)

Colorless solid m.p. 73.9- $74.8^{\circ} \mathrm{C} .{ }^{1} \mathrm{H}-\mathrm{NMR}\left(300 \mathrm{MHz}, \mathrm{CDCl}_{3}\right): \delta 7.32-7.16(\mathrm{~m}, 6 \mathrm{H}), 4.31(\mathrm{t}, J=7.1 \mathrm{~Hz}, 2 \mathrm{H}), 2.74-2.62(\mathrm{~m}, 4 \mathrm{H}), 2.23$ (quint, $J=7.4 \mathrm{~Hz}, 2 \mathrm{H}), 1.78(\mathrm{~s}, 3 \mathrm{H}), 1.69(\mathrm{~m}, J=7.4 \mathrm{~Hz}, 2 \mathrm{H}), 0.97(\mathrm{t}, J=7.3 \mathrm{~Hz}, 3 \mathrm{H}) .{ }^{13} \mathrm{C} \mathrm{NMR}\left(75 \mathrm{MHz}, \mathrm{CDCl}_{3}\right): \delta 148.5(\mathrm{C}), 140.3(\mathrm{C})$, 128.6 (CH), $128.4(\mathrm{CH}), 126.3(\mathrm{CH}), 120.5(\mathrm{CH}), 49.3\left(\mathrm{CH}_{2}\right), 32.6\left(\mathrm{CH}_{2}\right), 31.5\left(\mathrm{CH}_{2}\right), 29.2\left(\mathrm{CH}_{2}\right), 25.7\left(\mathrm{CH}_{2}\right), 22.4\left(\mathrm{CH}_{2}\right), 14.0\left(\mathrm{CH}_{3}\right)$. ESIHRMS Calcd. for $\left(\mathrm{M}+\mathrm{H}^{+}\right) \mathrm{C}_{14} \mathrm{H}_{20} \mathrm{~N}_{3} 230.1657$, found 230.1659 .

Synthesis of 4-pentyl-1-(3-phenylpropyl)-1H-1,2,3-triazole (7d)

Colorless oil. ${ }^{1} \mathrm{H}-\mathrm{NMR}\left(300 \mathrm{MHz}, \mathrm{CDCl}_{3}\right): \delta 7.32-7.16(\mathrm{~m}, 6 \mathrm{H}), 4.32(\mathrm{t}, J=7.1 \mathrm{~Hz}, 2 \mathrm{H}), 2.71(\mathrm{t}, J=7.6 \mathrm{~Hz}, 2 \mathrm{H}), 2.65(\mathrm{t}, J=7.8 \mathrm{~Hz}, 2 \mathrm{H})$, $2.26(\mathrm{p}, J=7.4 \mathrm{~Hz}, 2 \mathrm{H}), 1.71-1.62(\mathrm{~m}, 2 \mathrm{H}), 1.36-1.33(\mathrm{~s}, 4 \mathrm{H}), 0.90(\mathrm{t}, J=6.8 \mathrm{~Hz}, 3 \mathrm{H}) .{ }^{13} \mathrm{C} \mathrm{NMR}\left(75 \mathrm{MHz}, \mathrm{CDCl}_{3}\right): \delta 148.3(\mathrm{C}), 140.3(\mathrm{C})$, $128.5(\mathrm{CH}), 128.4(\mathrm{CH}), 126.2(\mathrm{CH}), 120.6(\mathrm{CH}), 49.3\left(\mathrm{CH}_{2}\right), 32.5\left(\mathrm{CH}_{2}\right), 31.7\left(\mathrm{CH}_{2}\right), 31.4\left(\mathrm{CH}_{2}\right), 29.2\left(\mathrm{CH}_{2}\right), 25.6\left(\mathrm{CH}_{2}\right), 22.4\left(\mathrm{CH}_{2}\right), 14.0$ $\left(\mathrm{CH}_{3}\right)$. ESI-HRMS Calcd. for $\left(\mathrm{M}+\mathrm{H}^{+}\right) \mathrm{C}_{16} \mathrm{H}_{24} \mathrm{~N}_{3} 258.1970$, found 258.1977.

Synthesis of 4-octyl-1-(3-phenylpropyl)-1H-1,2,3-triazole (7e)

Colorless solid m.p. 39.8- $40.8{ }^{\circ} \mathrm{C} .{ }^{1} \mathrm{H}-\mathrm{NMR}\left(300 \mathrm{MHz}^{\mathrm{CDCl}}\right)$ ): $\delta 7.32-7.16(\mathrm{~m}, 6 \mathrm{H}), 4.32(\mathrm{t}, J=7.1 \mathrm{~Hz}, 2 \mathrm{H}), 2.71(\mathrm{t}, J=7.6 \mathrm{~Hz}, 2 \mathrm{H}), 2.65$ $(\mathrm{t}, J=7.8 \mathrm{~Hz}, 2 \mathrm{H}), 2.24(\mathrm{p}, J=7.2 \mathrm{~Hz}, 2 \mathrm{H}), 1.71-1.62(\mathrm{~m}, 2 \mathrm{H}), 1.36-1.33(\mathrm{~s}, 4 \mathrm{H}), 0.90(\mathrm{t}, J=6.8 \mathrm{~Hz}, 3 \mathrm{H}) .{ }^{13} \mathrm{C} \mathrm{NMR}(75 \mathrm{MHz}, \mathrm{CDCl} 3): \delta$ $148.4(\mathrm{C}), 140.3(\mathrm{C}), 128.6(\mathrm{CH}), 128.4(\mathrm{CH}), 126.3(\mathrm{CH}), 120.5(\mathrm{CH}), 49.3\left(\mathrm{CH}_{2}\right), 32.5\left(\mathrm{CH}_{2}\right), 31.8\left(\mathrm{CH}_{2}\right), 31.7\left(\mathrm{CH}_{2}\right), 29.5\left(\mathrm{CH}_{2}\right), 29.3$ $\left(\mathrm{CH}_{2}\right), 29.3\left(\mathrm{CH}_{2}\right), 29.2\left(\mathrm{CH}_{2}\right), 25.7\left(\mathrm{CH}_{2}\right), 22.7\left(\mathrm{CH}_{2}\right), 14.1\left(\mathrm{CH}_{3}\right)$. ESI-HRMS Calcd. for $\left(\mathrm{M}+\mathrm{H}^{+}\right) \mathrm{C}_{19} \mathrm{H}_{30} \mathrm{~N}_{3} 300.2440$, found 300.2449.

Synthesis of 4-decyl-1-(3-phenylpropyl)-1H-1,2,3-triazole (7g)

Colorless solid m.p. 54.4- 55.4 ${ }^{\circ} \mathrm{C} .{ }^{1} \mathrm{H}-\mathrm{NMR}\left(300 \mathrm{MHz}, \mathrm{CDCl}_{3}\right): \delta 7.33-7.16(\mathrm{~m}, 6 \mathrm{H}), 4.32(\mathrm{t}, J=7.1 \mathrm{~Hz}, 2 \mathrm{H}), 2.73-2.63(\mathrm{~m}, 4 \mathrm{H}), 2.24(\mathrm{p}$, $J=7.4 \mathrm{~Hz}, 2 \mathrm{H}), 1.71-1.64(2 \mathrm{H}), 1.32-1.26(14 \mathrm{H}), 0.88(\mathrm{t}, J=6.5 \mathrm{~Hz}, 3 \mathrm{H}) .{ }^{13} \mathrm{C} \mathrm{NMR}\left(75 \mathrm{MHz}, \mathrm{CDCl}_{3}\right): \delta 148.4(\mathrm{C}), 140.3(\mathrm{C}), 128.5(\mathrm{CH})$, 128.4 (CH), $126.2(\mathrm{CH}), 120.5(\mathrm{CH}), 49.2\left(\mathrm{CH}_{2}\right), 32.5\left(\mathrm{CH}_{2}\right), 31.9\left(\mathrm{CH}_{2}\right), 31.7\left(\mathrm{CH}_{2}\right), 29.6\left(\mathrm{CH}_{2}\right), 29.6\left(\mathrm{CH}_{2}\right), 29.5\left(\mathrm{CH}_{2}\right), 29.4\left(\mathrm{CH}_{2}\right), 29.3$ $\left(\mathrm{CH}_{2}\right), 29.3\left(\mathrm{CH}_{2}\right), 25.7\left(\mathrm{CH}_{2}\right), 22.7\left(\mathrm{CH}_{2}\right), 14.1\left(\mathrm{CH}_{3}\right)$. ESI-HRMS Calcd. for $\left(\mathrm{M}+\mathrm{H}^{+}\right) \mathrm{C}_{21} \mathrm{H}_{34} \mathrm{~N}_{3} 328.2753$, found 328.2766.

Synthesis of 1-(1-(3-phenylpropyl)-1H-1,2,3-triazol-4-yl)ethanol (7h)

Colorless oil. ${ }^{1} \mathrm{H}-\mathrm{NMR}\left(\mathbf{3 0 0} \mathrm{MHz}, \mathrm{CDCl}_{3}\right): \delta 7.47(2 \mathrm{H}), 7.29-7.13(5 \mathrm{H}), 5.05(\mathrm{q}, J=6.5 \mathrm{~Hz}, 1 \mathrm{H}), 4.28(\mathrm{t}, J=7.1 \mathrm{~Hz}, 2 \mathrm{H}), 1.61(\mathrm{t}, J=7.2$ $\mathrm{Hz}, 2 \mathrm{H}$ ), 2.19 (quint, $J=7.2 \mathrm{~Hz}, 2 \mathrm{H}$ ), $1.55(\mathrm{~d}, J=6.7 \mathrm{~Hz}, 3 \mathrm{H}) .{ }^{13} \mathrm{C} \mathrm{NMR}\left(75 \mathrm{MHz}, \mathrm{CDCl}_{3}\right): \delta 152.6(\mathrm{C}), 140.2(\mathrm{C}), 128.6(\mathrm{CH}), 128.4(\mathrm{CH})$, $126.3(\mathrm{CH}), 120.3(\mathrm{CH}), 62.8\left(\mathrm{CH}_{2}\right), 49.5\left(\mathrm{CH}_{2}\right), 32.5\left(\mathrm{CH}_{2}\right), 31.6\left(\mathrm{CH}_{2}\right), 23.2\left(\mathrm{CH}_{3}\right)$. ESI-HRMS Calcd. for $\left(\mathrm{M}+\mathrm{H}^{+}\right) \mathrm{C}_{13} \mathrm{H}_{18} \mathrm{~N}_{3} \mathrm{O} 232.1450$, found 232.1447 .

\subsection{Biology}

In vitro activity against $P$. falciparum $\left(I C_{50}\right)$

Antimalarial activity was determined in vitro on the chloroquine sensitive (D6, Sierra Leone) and resistant (W2, Indo China) strains of $P$. falciparum. The 96-well microplate assay was based on the evaluation of the effect of compounds on the growth of asynchronous cultures of $P$. falciparum, determined by the assay of parasite lactate dehydrogenase (pLDH) activity. The appropriate dilutions of the compounds (dissolved in DMSO) were prepared in RPMI-1640 medium and added to the cultures of $P$. falciparum ( $2 \%$ hematocrit, $2 \%$ parasitemia) setup in clear flat bottomed 96 -well plates. The plates were placed into the humidified chamber and flushed with a gas mixture of $90 \% \mathrm{~N}_{2}, 5 \% \mathrm{CO}_{2}$ and $5 \% \mathrm{O}_{2}$. The cultures were incubated at $37^{\circ} \mathrm{C}$ for $48 \mathrm{~h}$. Growth of the parasite in each well was determined by pLDH assay using Malstat reagent. The medium and red blood cells (RBC) controls were also setup in each plate. The standard antimalarial agent chloroquine and artemisinin were used as the positive controls. Add a reference of your previous paper with antimalarial activity (or any other reference for example Maurya et al 2019 Eur. J. Med Chem vol 162, 277-289)

In vitro activity against L. donovani $\left(I C_{50}\right)$

Leishmania donovani promastigotes of the S1 Sudan strain $\left(2 \times 10^{6} \mathrm{cell} / \mathrm{mL}\right)$ were cultured at $26^{\circ} \mathrm{C}$ in polystyrene cell-culture flasks $\left(25 \mathrm{~cm}^{2}\right)$, containing RPMI-1640 medium (without sodium bicarbonate and sodium pyruvate) with $10 \%$ FBS. Subculture of $L$. donovani promastigotes twice a week, with highest cells concentration in the range of $20-25 \times 10^{6}$ promastigotes $/ \mathrm{mL}$.

In vitro Antileishmanial assays: Antileishmanial activity of the compounds was tested in vitro on a culture of $L$. donovani promastigotes. In a 96-well microplate the compounds with appropriate dilution were added to the promastigotes culture $\left(2 \times 10^{6}\right.$ 
cell $/ \mathrm{mL}$ ) to get the final concentrations of 40,8 and $1.6 \mu \mathrm{g} / \mathrm{mL}$. The plates were incubated at $26^{\circ} \mathrm{C}$ for 72 hours and growth was determined by Alamar blue assay. ${ }^{53}$ Pentamidine and Amphotericin B were tested as the standard antileishmanial agents.

Statistics and data analysis: $I_{50}$ values were obtained by non-linear regression of dose response logistic functions, using the Microsoft Excel-based plug-in XLfit. All experiments were performed in triplicate.

Cytotoxicity assay on Vero cells

Vero cells (African green monkey kidney) were cultured in RPMI medium supplemented with $10 \%$ heat inactivated FCS, $0.15 \%$ (w/v) $\mathrm{NaHCO}_{3}, 100 \mathrm{U} / \mathrm{mL}$ penicillin and $100 \mathrm{U} / \mathrm{mL}$ streptomycin at $37^{\circ} \mathrm{C}$ in an atmosphere of $5 \% \mathrm{CO}_{2}$ and $95 \%$ humidity.

Cytotoxicity assays: Neutral Red assay was used to evaluate the cytotoxicity of analogs. Vero cells were plated on 96 -well plate and upon confluency, incubated with various concentrations of each analog (at a maximum concentration of $4.75 \mu \mathrm{g} / \mathrm{mL}$ ) for 48 hours at $37^{\circ} \mathrm{C}$ in a cell culture incubator. Cell viability was measured and $I C_{50}$ value for each compound was computed from the concentration response curve. ${ }^{39,54}$

\section{Conclusions}

We have previously shown that prenyl and aliphatic triazoles are interesting motifs that provided new chemical entities for antiparasitic and antitubercular drug development. In this opportunity the previously reported collections were expanded with 20 new analogs. The complete collection of 64 compounds was tested on two different strains of the malaria parasite ( $P$. falciparum) and the antileishmanial activity was evaluated on promastigotes of $L$. donovani. Only 13 analogs displayed antimalarial activity. The antileishmanial activity of newly tested analogs was less potent than the previously reported analogs.

Based on their activity and selectivity, compounds $\mathbf{1 0}$ and $\mathbf{1 r}$ were selected as the most promising antimalarial drug candidates. (Fig. 9) Based on their structure, a mechanism of action where they could be interfering in the isoprene metabolism has been proposed. The farnesyl pyrophosphate synthase is the most promising molecular target, nevertheless the participation of other validated enzymes like farnesyl transferase could not be excluded. Those hypotheses will be further validated, as long as the modification of the analogs $\mathbf{1 g}, \mathbf{1 0}, \mathbf{1 r}$ and $\mathbf{9 a}$ to develop malaria-visceral leishmaniasis co-infection treatments.

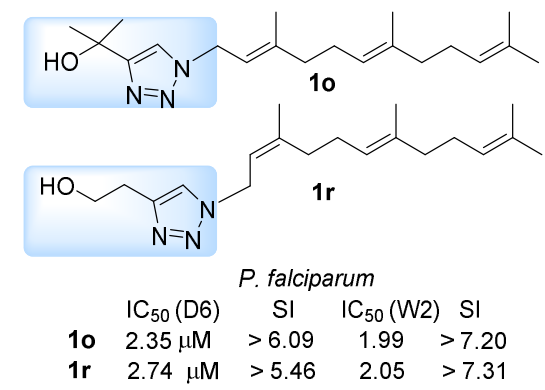

Fig. 9. Most promising antimalarial compounds of the synthesized chemical library.

\section{Conflicts of interest}

There are no conflicts to declare.

\section{Acknowledgements}

This work was supported in part by grants from UNR (Universidad Nacional de Rosario 80020190300101 UR), CONICET, Agencia Nacional de Promoción Científica y Tecnológica (ANPCyT PICT- 2017-2096 awarded to G.R.L.) The research leading to these results has, in part, received funding from UK Research and Innovation via the Global Challenges Research Fund under grant agreement ' $A$ Global Network for Neglected Tropical Diseases' grant number MR/P027989/1. GRL is a member of the Research Career of the Consejo Nacional de Investigaciones Científicas y Técnicas of Argentina (CONICET). R.C. thanks CONICET for the award of a fellowship.

\section{Notes and references}

1. J. M. W. C. Subhash Ghosh, Christopher R. Lea, Gary A. Meints, Jared C. Lewis, Zev S. Tovian, Ryan M. Flessner, Timothy C. Loftus, Iris Bruchhaus, Howard Kendrick, Simon L. Croft, Robert G. Kemp, Seiki Kobayashi, Tomoyoshi Nozaki, and Eric Oldfield, J. Med. Chem., 2004, 47, 175-187.

2. WHO, World malaria report 2017. 
N. N. H. Valero and M. Uriarte, Parasitol. Res., 2020, 119, 365-384.

4. J. L. Margaret A. Phillips, Kennan Marsh, John White, Anthony Dayan, Karen L. White, Jacqueline W. Njoroge, Farah El Mazouni, Yanbin Lao, Sreekanth Kokkonda, Diana R. Tomchick, Xiaoyi Deng, Trevor Laird, Sangeeta N. Bhatia, Sandra March, Caroline L. Ng, David A. Fidock, Sergio Wittlin, Maria Lafuente-Monasterio, Francisco Javier Gamo Benito, Laura Maria Sanz Alonso, Maria Santos Martinez, Maria Belen Jimenez-Diaz, Santiago Ferrer Bazaga, Iñigo Angulo-Barturen, John N. Haselden, James Louttit, Yi Cui, Arun Sridhar, Anna-Marie Zeeman, Clemens Kocken, Robert Sauerwein, Koen Dechering, Vicky M. Avery, Sandra Duffy, Michael Delves, Robert Sinden, Andrea Ruecker, Kristina S. Wickham, Rosemary Rochford, Janet Gahagen, Lalitha Iyer, Ed Riccio, Jon Mirsalis, Ian Bathhurst, Thomas Rueckle, Xavier Ding, Brice Campo, Didier Leroy, M. John Rogers, Pradipsinh K. Rathod, Jeremy N. Burrows and Susan A. Charman., Sci. Transl. Med., 2015, 7 $296 r a 111$. J. A. S. Ric N. Price, François Nosten, Christine Luxemburger, Lili Hkirjaroen, Feiko ter Kuile, Tan Chongsuphajaisiddhi, and Nicholas J. White, Am. J. Trop. Med. Hyg., 2001, 65, 614-622.

6. B. Q. Amino R, Baum J, Billker O, Bogyo M, Bousema T, Christophides G, Deitsch K, Dinglasan R, Djimde A, Duraisingh M, Dzinjalamala F, Happi C, Heussler V, Kramarik J, de Koning-Ward T, Lacerda M, Laufer M, Lim P, Llinas M, McGovern V, Martinez-Barnetche J, Mota M, Mueller I, Okumu F, Rasgon J, Serazin A, Sharma P, Sinden R, Wirth D, Gilberger T, PLoS Med., 2011, 8, e1000399. M. Shrestha, M. Khatri-Chhetri, R. C. Poudel, J. Maharjan, S. P. Dumre, K. D. Manandhar, B. D. Pandey, S. B. Pun and K. Pandey, BMC Infect. Dis., 2019, 19, 444.

8. L. H. C. Sangenis, S. R. d. A. Lima, C. X. d. Mello, D. T. Cardoso, J. N. Mello, M. C. C. d. E. Santo and W. Tavares, Rev. Inst. Med. Trop. Sao Paulo, 2014, 56, 271-274.

9. Y. Aschale, A. Ayehu, L. Worku, H. Tesfa, M. Birhanie and W. Lemma, BMC Infect. Dis., $2019,19,239$.

10. E. van den Bogaart, M. M. Z. Berkhout, A. B. Y. M. Nour, P. F. Mens, A.-B. A. Talha, E. R. Adams, H. B. M. Ahmed, S. H. Abdelrahman, K. Ritmeijer, B. Y. M. Nour and H. D. F. H. Schallig, BMC Public Health, 2013, $13,332$. F. B. Agusto and E. L. IM, PLoS One, 2017, 12, e0171102.

G. R. Pereira, G. C. Brandão, L. M. Arantes, H. A. De Oliveira Jr, R. C. De Paula, M. F. A. Do Nascimento, F. M. Dos Santos, R. K. Da Rocha, J. C. D. Lopes and A. B. De Oliveira, Eur. J. Med. Chem., 2014, 73, 295-309.

K. F. Suazo, C. Schaber, C. C. Palsuledesai, A. R. Odom John and M. D. Distefano, Sci. Rep., 2016, 6, 38615.

S. R. B. Uliana, C. T. Trinconi and A. C. Coelho, Parasitology, 2018, 145, 464-480.

J. D. S. a. J. S. S.-L. Michael H. Gelb, Curr. Opin. Chem. Biol., 1998, 2, 40-48.

D. D. S. Chakrabarti, T.; Barger, J.; Paquette, S.; Patel, H.; Patterson, S. and C. M. Allen, J. Biol. Chem., 2002, 277, 4206642073.

19. 175-184.

20.

21.

22.

23.

24. M. Brioschi, A. Martinez Fernandez and C. Banfi, Expert Rev. Proteom, 2017, 14, 515-528.

A. Srivastava, P. Mukherjee, P. V. Desai, M. A. Avery and B. L. Tekwani, Infect. Disord. Drug Targets, $2008,8,16-30$.

J. B. Rodriguez, B. N. Falcone and S. H. Szajnman, Expert Opin. Drug Discov., 2016, 11, 307-320.

D. Mukkamala, J. H. No, L. M. Cass, T.-K. Chang and E. Oldfield, J. Med. Chem., 2008, 51, 7827-7833.

A. P. Singh, Y. Zhang, J.-H. No, R. Docampo, V. Nussenzweig and E. Oldfield, Antimicrob. Agents Chemother., 2010, 54, 2987-2993.

25. J. H. No, F. de Macedo Dossin, Y. Zhang, Y. L. Liu, W. Zhu, X. Feng, J. A. Yoo, E. Lee, K. Wang, R. Hui, L. H. Freitas-Junior and E. Oldfield, Proc. Natl. Acad. Sci. USA, 2012, 109, 4058-4063. J. D. Artz, A. K. Wernimont, J. E. Dunford, M. Schapira, A. Dong, Y. Zhao, J. Lew, R. G. Russell, F. H. Ebetino, U. Oppermann and R. Hui, J. Biol. Chem., 2011, 286, 3315-3322.

S. H. Szajnman, A. Montalvetti, Y. Wang, R. Docampo and J. B. Rodriguez, Bioorg. Med. Chem. Lett., 2003, 13, 3231-3235.

S. H. Szajnman, G. E. Garcia Linares, Z. H. Li, C. Jiang, M. Galizzi, E. J. Bontempi, M. Ferella, S. N. Moreno, R. Docampo and J. B. Rodriguez, Bioorg. Med. Chem., 2008, 16, 3283-3290.

29. 2011, 19, 2211-2217. Modriguez, Eur. J. Med. Chem., 2013, 60, 431-440.

30.

31.

J. E. Gisselberg, Z. Herrera, L. M. Orchard, M. Llinás and E. Yeh, Cell Chemical Biology, 2018, 25, 185-193.e185.

A. Rani, G. Singh, A. Singh, U. Maqbool, G. Kaur and J. Singh, RSC Adv., 2020, 10, 5610-5635.

K. Bozorov, J. Zhao and H. A. Aisa, Bioorg. Med. Chem., 2019, 27, 3511-3531.

M. C. Joshi, K. J. Wicht, D. Taylor, R. Hunter, P. J. Smith and T. J. Egan, European Journal of Medicinal Chemistry, 2013, 69, 338-347.

N. Boechat, L. Ferreira Mde, L. C. Pinheiro, A. M. Jesus, M. M. Leite, C. C. Junior, A. C. Aguiar, I. M. de Andrade and A. U. Krettli, Chem. Biol. Drug Des., 2014, 84, 325-332.

E. O. Porta, P. B. Carvalho, M. A. Avery, B. L. Tekwani and G. R. Labadie, Steroids, 2014, 79, 28-36.

X. M. Chu, C. Wang, W. L. Wang, L. L. Liang, W. Liu, K. K. Gong and K. L. Sun, Eur. J. Med. Chem., 2019, 166, 206-223.

P. Kumar, A. O. Achieng, V. Rajendran, P. C. Ghosh, B. K. Singh, M. Rawat, D. J. Perkins, P. Kempaiah and B. Rathi, Sci Rep, 2017, 7, 6724.

S. Balabadra, M. Kotni, V. Manga, A. D. Allanki, R. Prasad and P. S. Sijwali, Bioorg. Med. Chem., 2017, 25, 221-232.

E. O. J. Porta, S. N. Jäger, I. Nocito, G. I. Lepesheva, E. C. Serra, B. L. Tekwani and G. R. Labadie, MedChemComm, 2017, 8, 1015-1021.

G. R. Labadie, A. de la Iglesia and H. R. Morbidoni, Mol. Divers., 2011, 15, 1017-1024. 
41. A. S. Thompson, G. R. Humphrey, A. M. DeMarco, D. J. Mathre and E. J. J. Grabowski, J. Org. Chem., 1993, 58, 5886-5888.

42. E. O. J. Porta, M. M. Vallejos, A. B. J. Bracca and G. R. Labadie, RSC Adv., 2017, 7, 47527-47538.

43. D. G. Ghiano, A. de la Iglesia, N. Liu, P. J. Tonge, H. R. Morbidoni and G. R. Labadie, Eur. J. Med. Chem., 2017, 125, 842852.

44. P. Y. Muller and M. N. Milton, Nature Reviews Drug Discovery, 2012, 11, 751.

45. S. Kabeche, J. Aida, T. Akther, T. Ichikawa, A. Ochida, M. J. Pulkoski-Gross, M. Smith, P. S. Humphries and E. Yeh, Bioorg. Med. Chem. Lett., 2021, 41, 127978.

46. A. Gaulton, A. Hersey, M. Nowotka, A. P. Bento, J. Chambers, D. Mendez, P. Mutowo, F. Atkinson, L. J. Bellis and E. Cibrián-Uhalte, Nucleic Acids Res., 2017, 45, D945-D954.

47. https://chemminetools.ucr.edu/.

48. S. Kar and J. Leszczynski, Expert Opin. Drug Discov., 2020, 15, 1473-1487.

49. http://www.organic-chemistry.org/prog/peo/.

50. http://www.molinspiration.com. v2014.11, 20-08-2015.

51. C. A. Lipinski, F. Lombardo, B. W. Dominy and P. J. Feeney, Adv. Drug Del. Rev., 1997, 23, 3-25.

52. D. F. Veber, S. R. Johnson, H.-Y. Cheng, B. R. Smith, K. W. Ward and K. D. Kopple, J. Med. Chem., 2002, 45, $2615-2623$.

53. J. Mikus and D. Steverding, Parasitol. Int., 2000, 48, 265-269.

54. J. Fernández de Luco, A. I. Recio-Balsells, D. G. Ghiano, A. Bortolotti, J. M. Belardinelli, N. Liu, P. Hoffmann, C. Lherbet, P. J. Tonge, B. Tekwani, H. R. Morbidoni and G. R. Labadie, RSC Med. Chem., 2021, 12, 120-128. 